\title{
Antimicrobial effect of nisin in processed cheese - Quantification of residual nisin by LC-MS/MS and development of new growth and growth boundary model for Listeria monocytogenes
}

Martinez Rios, Veronica; Pedersen, Mikael; Pedrazzi, Monica; Gkogka, Elissavet; Smedsgaard, Jørn; Dalgaard, Paw

Published in:

International Journal of Food Microbiology

Link to article, DOI:

10.1016/j.ijfoodmicro.2020.108952

Publication date:

2021

Document Version

Peer reviewed version

Link back to DTU Orbit

Citation (APA):

Martinez Rios, V., Pedersen, M., Pedrazzi, M., Gkogka, E., Smedsgaard, J., \& Dalgaard, P. (2021). Antimicrobial effect of nisin in processed cheese - Quantification of residual nisin by LC-MS/MS and development of new growth and growth boundary model for Listeria monocytogenes. International Journal of Food Microbiology, 338, [108952]. https://doi.org/10.1016/j.ijfoodmicro.2020.108952

\section{General rights}

Copyright and moral rights for the publications made accessible in the public portal are retained by the authors and/or other copyright owners and it is a condition of accessing publications that users recognise and abide by the legal requirements associated with these rights.

- Users may download and print one copy of any publication from the public portal for the purpose of private study or research.

- You may not further distribute the material or use it for any profit-making activity or commercial gain

- You may freely distribute the URL identifying the publication in the public portal 


\section{Journal Pre-proof}

Antimicrobial effect of nisin in processed cheese - quantification of residual nisin by LC-MS/MS and development of new growth and growth boundary model for Listeria monocytogenes

Veronica Martinez-Rios, Mikael Pedersen, Monica Pedrazzi, Elissavet Gkogka, Jørn Smedsgaard, Paw Dalgaard

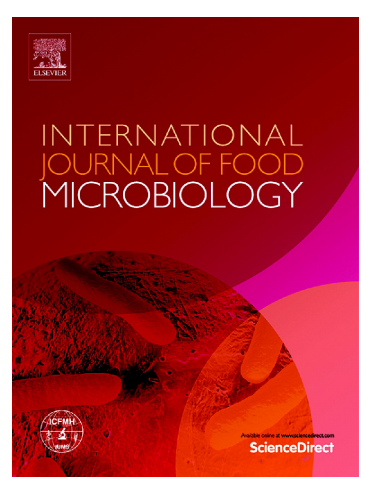
PII:
S0168-1605(20)30446-3
DOI:
https://doi.org/10.1016/j.ijfoodmicro.2020.108952
Reference:
FOOD 108952

To appear in:

International Journal of Food Microbiology

Received date:

3 June 2020

Revised date:

25 August 2020

Accepted date:

25 October 2020

Please cite this article as: V. Martinez-Rios, M. Pedersen, M. Pedrazzi, et al., Antimicrobial effect of nisin in processed cheese - quantification of residual nisin by LC-MS/MS and development of new growth and growth boundary model for Listeria monocytogenes, International Journal of Food Microbiology (2020), https://doi.org/ 10.1016/j.ijfoodmicro.2020.108952

This is a PDF file of an article that has undergone enhancements after acceptance, such as the addition of a cover page and metadata, and formatting for readability, but it is not yet the definitive version of record. This version will undergo additional copyediting, typesetting and review before it is published in its final form, but we are providing this version to give early visibility of the article. Please note that, during the production process, errors may be discovered which could affect the content, and all legal disclaimers that apply to the journal pertain.

(C) 2020 Published by Elsevier. 
Antimicrobial effect of nisin in processed cheese - Quantification of residual nisin by LC-MS/MS and development of new growth and growth boundary model for Listeria monocytogenes

Veronica Martinez-Rios ${ }^{1}$, Mikael Pedersen ${ }^{1}$, Monica Pedrazzl ${ }^{1,3}$, Elissavet Gkogka ${ }^{2}$, Jørn Smedsgaard $^{1}$, Paw Dalgaard ${ }^{1}$

${ }^{1}$ National Food Institute (DTU Food), Technical U iv e sity of Denmark, Kgs. Lyngby, Denmark

${ }^{2}$ Arla Innovation Centre, Arla Foods amba, Ar hus N, Denmark

* Corresponding author: Foct $\mathrm{N}$ icrobiology and Hygiene, National Food Institute, Technical University of Denmark, Kımi orvet, Building 204, DK-2800, Kgs. Lyngby, Denmark. E-mail: veri.food.dtu.dk (V. Martinız-Rios)

${ }^{3}$ Present address: Via dell'industria 3, Verona, Italy. 


\section{ABSTRACT}

This study tested the hypothesis that growth of Listeria monocytogenes in processed cheese with added nisin can be predicted from residual nisin A concentrations in the final product after processing. A LC-MS/MS method and a bioassay were studied to quantify residual nisin A concentrations and a growth and growth boundary model was developed to predict the antilisterial effect in processed cheese. 278 growth rates were determined in broth for $11 \mathrm{~L}$. monocytogenes isolates and used to determine 13 minimum inhibitory concentration, $M I C$ ) values for nisin between pH 5.5 and 6.5. To supplement these data, 67 MIC-values $\because$ tinerent pH-values were collected from the scientific literature. A MIC-term was developed to tescribe the effect of $\mathrm{pH}$ on nisin MICvalues. An available growth and growth boundary moi i (doi: 10.1016/j.fm.2019.103255) was expanded with the new MIC-term for nisin to pred $\because g$ owth in processed cheese. To generate data for model evaluation and further model $d \mathrm{ve}^{1}$ spment, challenge tests with a total of 45 growth curves, were performed using processed .heese. Cheese were formulated with 11.2 or $12.0 \mathrm{ppm}$ of nisin $\mathrm{A}$ and heat treated to obtain resici al nisin A concentrations ranging from 0.56 to $5.28 \mathrm{ppm}$. Below $15^{\circ} \mathrm{C}$, nisin resulted in ext ndt $\mathrm{dag}$ times. A global regression approach was used to fit all growth curves determined in $c_{1}$, lle ige tests. This was obtained by combining the secondary growth and growth boundary mu ${ }^{\top} e_{1}$ :- duding the new term for the inhibiting effect of nisin on $\mu_{\max }$ with the primary logistic growth model with delay. This model appropriately described the growth inhibiting effect of residual nisin $\mathrm{A}$ and showed that relative lag times depended on storage temperatures. With residual nisin A concentrations, other product characteristics and storage temperature as input the new model correctly predicted all observed growth and no-growth responses for L. monocytogenes. This model can support development of nisin A containing recipes for processed cheese that prevent growth of L. monocytogenes. Residual nisin A concentrations in processed cheese were accurately quantified by the developed LC-MS/MS method with recoveries 
of 83 to $110 \%$ and limits of detection and quantification being 0.04 and $0.13 \mathrm{ppm}$, respectively. The tested bioassay was less precise and nisin A recoveries varied for $53 \%$ to $94 \%$.

Keywords: Cardinal parameter model, global regression, growth boundary, $\psi$-value, product development

\section{Introduction}

Nisin A is an antimicrobial peptide belonging to the lan ibio ic class of bacteriocins (Class I), composed of 34 aminoacids and with a molecular me is of $3.5 \mathrm{kDa}$. Nisin has antimicrobial activity against a wide range of Gram-positive food- $b$ orne pathogens and it influences both cell membrane pore formation and cell wall synth ss, (Cotter et al., 2005). Commercial nisin preparations have been used for over 30 ye.$\star a_{1}{ }^{d}$ are allowed in foods as an added preservative (FDA, 1988; Thomas and Delves-Broughton, 2905). Nisin is used in processed cheese to control potential growth of spore-forming bac er. ine anaerobic environment, high moisture and $\mathrm{pH}$ of 5.4 to 6.0 usually found in proce sed theese may allow germination of spores and growth of Clostridium spp. or facultative an? 'erobic Bacillus spp. if present in the product and not controlled by means of formulation ( )elv :s-Broughton, 2008; Glass et al., 2017). Though nisin has a welldocumented use for the $\mathrm{cnn}^{\prime} \mathrm{col}$ of these spore-forming bacteria in processed cheese formulations, little information is available with regards to its protective effect against vegetative pathogens such as L. monocytogenes, that may contaminate these products during consumer handling (Redmond and Griffith, 2003).

The antimicrobial activity of nisin against L. monocytogenes has been studied in broth or agar by determination of minimum inhibitory concentration (MIC) (Benkerroum and Sandine, 1988; Ferreira and Lund 1996; Martínez and Rodríguez, 2005). Furthermore, several nisin 
bioassays have been developed over the years to measure the antimicrobial activity of nisin. The most widely used bioassay is the horizontal agar diffusion method relying on a test microorganism (Fowler et al., 1975; Papagianni et al., 2006; Tramer and Fowler, 1964). When estimating residual nisin $\mathrm{A}$ in foods one has to use a method describing the extraction of nisin $\mathrm{A}$ from foodstuffs. However, no information is available about recovery and precision for bioassays when used to estimate residual nisin A in foods (Pongtharangkul and Demirci, 2004; Rogers and Montville, 1991).

In the last years, more advance analytical methods have reen developed to quantify nisin A present in foods. An ISO standard has been published for tl e ntification of nisin A in cheese by liquid chromatography/mass spectroprometry (LC-Ms an 1 LC-MS/MS (ISO, 2009). This LCMS/MS method has been used to quantify nisin A ¿1 .ifferent types of cheeses (Fuselli et al., 2012; Ko et al., 2016; Schneider et al., 2011). H H ew $^{\prime}$, the relation between concentrations of nisin measured by LC-MS/MS and its antimicrobial a 'tivity has not been studied.

The objectives of the present st $\mathrm{d}_{\mathrm{y}}$ were to develop and validate a LC-MS/MS method for quantification of residual nisin $\mathrm{A} \cap \eta$ different cheeses and to determine the inhibitory effect of residual nisin A concentrations on growth responses of $L$. monocytogenes in cheese. The antilisterial effect of nisin A $\mathrm{u}$ as studied by using a predictive food microbiology approach for comparison of observed and predicted growth. Firstly, a nisin MIC-term was developed including the effect of $\mathrm{pH}$ on nisin MIC-values and this term was added to an available cardinal parameter growth and growth boundary model. Secondly, processed cheese with added nisin A was studied by challenge testing to quantify growth of L. monocytogenes at different constant storage temperatures and product characteristics $\left(\mathrm{pH}, \mathrm{a}_{\mathrm{w}}\right.$, lactic-, acetic-, citric acids, orthophosphate salt and nisin $\mathrm{A}$ concentrations). These data was used to developed a simple secondary model for relative lag time (RLT). Lastly, the expanded growth and growth boundary model was evaluated by comparison of 
observed and predicted growth for L. monocytogenes in cheeses when (a) assuming absence of nisin A, (b) using residual nisin A concentrations measured by LC-MS/MS and (c) using concentrations of nisin A added to the cheeses at formulation.

\section{Materials and methods}

\subsection{Nisin and stock solutions}

Nisin stock solutions (50 ppm and $500 \mathrm{ppm})$ were pref areo with Nisaplin $(2.5 \%$ nisin A, Danisco, batch number 4263501621 ) by adding $0.020 \mathrm{~g}$ or $(.2 \mathrm{nr}, \mathrm{g}$ to $10 \mathrm{ml}$ of $0.02 \mathrm{~N} \mathrm{HCl}$. These stock solutions were stored at $4^{\circ} \mathrm{C}$ for a maximum of 24 hous.

\subsection{Nisin quantification by LC-MS/MS}

\subsubsection{Nisin extraction method for LC-1 1s M M analysis}

Methanol:water (1:1 v/v) (: PLC grade, VWR chemicals, Søborg, Denmark) with 0.1\% formic acid (695076, Sigma-Ald $-h$, St. Louis, MO, USA) adjusted with $5 \mathrm{M} \mathrm{HCl}$ to $\mathrm{pH} 2.0$ was used as solvent to extract nis $\mathrm{n}$ A from cheese. Cheese $(2.0 \mathrm{~g})$ was homogenized in $30 \mathrm{~mL}$ extraction solvent with a T2 ${ }^{6}$ Ultra Turrax (IKA, Staufen, Germany). The suspension was sonicated for $10 \mathrm{~min}$. at room temperature and then centrifuged (Eppendorf centrifuge $5810 \mathrm{R}$, Hørsholm, Denmark) at $4500 \mathrm{rpm}$ for $20 \mathrm{~min}$ at $4^{\circ} \mathrm{C}$. The supernatant was transferred to a volumetric flask and the precipitate was washed/extracted twice with $10 \mathrm{~mL}$ extraction solvent. Supernatants were combined and supplemented as necessary with extraction solvent to $50 \mathrm{ml}$ and then filtered $(0.2 \mu \mathrm{m}$ Ministart ${ }^{\circledR}$, Sartorius Stedim Biotech $\mathrm{GmbH}$ ) prior to LC-MS/MS analysis. 


\subsubsection{LC-MS/MS analysis}

For the LC-MS/MS analysis (Table 1), an EVOQ Elite ${ }^{\mathrm{TM}}$ triple quadrupole mass spectrometer (Bruker, Frederikssund, Denmark), equipped with an electrospray ionization (ESI) source was coupled to an UltiMate 3000 ultra-high-performance liquid chromatography system (UHPLC) from Dionex Thermo scientific (Waltham, MA, USA). The UHPLC consisted of a pump, autosampler and column compartment. Chromeleon Xpress (Thermo Fisher Scientific, Waltham, USA) and MS Workstation 8 (Agilent, Santa Clara, USA) were $\mathrm{u}_{\llcorner} \cdot \mathrm{d}$ to perform system control and data acquisition on the UHPLC and mass spectrometer, respec ivel $r$. Chromatographic separation was performed using a Zorbax 300 SB-C18 column (Table ${ }^{*}$ ).

The mobile phase consisted of an aqueous solut $\cdot \mathrm{n}$ u ith $0.1 \%$ formic acid (mobile phase A) and $100 \%$ acetonitrile (mobile phase B; Chromasr $1 \mathrm{v}^{\mathrm{TM}}$ LC-MS, Honeywell, Seelze, Germany). A

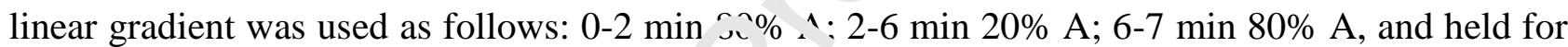
3 min to equilibrate the column. The columı was maintained at $40^{\circ} \mathrm{C}$. The flow rate was 0.3 $\mathrm{mL} / \mathrm{min}$ and the injection volume for th 2 i. $\sin$ standards $(0.1,0.5,1,2.5,5,10 \mathrm{ppm})$ or samples was $10 \mu \mathrm{l}$. The diverter valve was usc:' to eliminate $\mathrm{NaCl}$ interferences, directing the flow into the discharge for the first 3 minutes $\iota^{f}$ each run, avoiding contamination of the ion source. The parent ion $[\mathrm{M}+4 \mathrm{H}]^{4+}$ was identifie $\mathrm{l}$ as 839.0 (average mass, 3354). The fragment ions of nisin $\mathrm{A}$ were selected as 1081 (quantitative ion) and 811 (qualitative ion). Diagnostic ions were found using an infusion experiment. A standard solution of nisin A (1 ppm) was infused directly into the ion source without applying collision gas and collision energy to identify parent ions. Fragment ions were likewise identified with infusion of standard solution and collision gas and collision energy applied.

\subsubsection{Calculation of nisin A}

Content of nisin A in cheese samples was calculated using eq. (1). 


$$
\operatorname{Nisin} A(p p m)=\frac{H_{t} \cdot \rho_{n A, s} \cdot V_{t}}{H_{s} \cdot m_{t}}
$$

where $H_{\mathrm{t}}$ is the test sample peak area, $\rho_{\mathrm{nA}, \mathrm{s}}$ is the concentration in ppm of the standard solution used to construct the calibration curve, $V_{\mathrm{t}}$ is the test sample volume $(50 \mathrm{ml}), H_{\mathrm{s}}$ is the peak area of $\rho_{\mathrm{nA}, \mathrm{s}}$ and $m_{\mathrm{t}}$ is the mass $(\mathrm{g})$ of cheese sample.

\subsection{Nisin quantification by bioassay}

The method described in this section combined a nim nisin extraction method and quantification by a plate diffusion assay with an indicator o. ranısm (Tramer and Fowler, 1964).

\subsubsection{Nisin extraction for the bioassay}

Cheese $(2.0 \mathrm{~g})$ was macerated in a $5 \mathrm{~J} \mathrm{~m}$. glass beaker using $10 \mathrm{~mL}$ of $0.02 \mathrm{~N} \mathrm{HCl}$ with $\mathrm{pH}$ 2.0 and magnet stirring for $30 \mathrm{~min}$. Ther after the mixture was place on a hot plate (pre-heat to 100 ${ }^{\circ} \mathrm{C}$ ) with magnetic stirring and boiled $10.5 \mathrm{~min} .40 \mathrm{ml}$ of $0.02 \mathrm{~N} \mathrm{HCl} \mathrm{was} \mathrm{used} \mathrm{to} \mathrm{wash} \mathrm{the} \mathrm{beaker}$ and the sample was transfer to a $0^{6} \mathrm{~h}^{1}$ falcon tube and centrifuged at $4500 \mathrm{rpm}$ for $20 \mathrm{~min}$ at $4^{\circ} \mathrm{C}$ (Eppendorf centrifuge $5810 \mathrm{~K}, \mathrm{H} \emptyset$ sholm, Denmark). The supernatant with nisin was analysed as described below.

\subsubsection{Indicator organism and pre-culture conditions}

Preliminary studies with both Micrococcus luteus DSM 1790 and Lactobacillus sakei ATCC 15521 as indicator organisms were performed. Quantification of nisin did not differ between the two indicator organisms and M. luteus was retained as its yellow colonies produced a more clear inhibition zone. M. luteus DSM 1790 was transferred from storage at $-80^{\circ} \mathrm{C}$ to Nutrient broth (NB) (CM001, Oxoid, Hampshire, UK) and incubated for $24 \mathrm{~h}$ at $30^{\circ} \mathrm{C}$. Subsequently, the culture with $M$. 
luteus was streaked on NB agar (1.3\%) plates and incubated for $48 \mathrm{~h}$ at $30^{\circ} \mathrm{C} .200 \mathrm{ml} \mathrm{NB}$ containing a magnet was inoculated with a single colony and incubated at $30^{\circ} \mathrm{C}$ with stirring $(200 \mathrm{rpm})$ for 24h. The cell concentration was then determined by direct phase contrast microscopy at $1000 \mathrm{x}$ magnification considering that one cell per field of view corresponded to a concentration around $10^{6}$ cfu/ml (Adams and Moss, 2016).

\subsubsection{Agar diffusion bioassay}

Molten NB (1.3\%) agar tempered at $48^{\circ} \mathrm{C}$ was supn 'me ited with $2 \%$ of a $1: 1$ mixture of Tween 20 (P9416, Sigma-Aldrich, St. Louis, USA) and cer'e water, previously held for 30 minutes at $48^{\circ} \mathrm{C}$, and thoroughly mixed. The medium agar $(2 \mathrm{n} \cap \mathrm{ml}$ bottles $)$ were held for 30 minutes at $46^{\circ} \mathrm{C}$ and then inoculated with the indicator organism $~ ?$ reach a final concentration of $10^{6} \mathrm{cfu} / \mathrm{ml} .20 \mathrm{ml}$ of inoculated medium was placed in each ste. 'e Petri dish $(100$ x $20 \mathrm{~mm})$. After agar solidification at room temperature, wells of $5 \mathrm{~mm}$ dir..ett: were made with a cork borer. $30 \mu \mathrm{lof}$ nisin standard solutions $\left(0.1,0.5,1,2.5,5,10 \mathrm{r} n_{1} ; \mathrm{pH} 2.0\right)$ were placed in each well and the plates were incubated at $30^{\circ} \mathrm{C}$ for $72 \mathrm{~h}$. The ' on images of the plates by using an automated image analyser software (ImageJ Basics, v. 1.38, 2008). Four zones were $m_{\imath}$ asured for each nisin concentration and assays were performed in triplicate on three different days $(n=4 \times 3 \times 3)$.

\subsection{Evaluation of methods for quantification of nisin}

The quantification methods were evaluated for linearity, specificity, recovery and precision (NMKL, 2009). The only difference in the evaluation of the methods studied was the used of two matrixes (PC and SPC) for LC-MS/MS or exclusively one (SPC) for the evaluation of the bioassay. Standard curves with four concentrations (including zero) (x-axis) and the corresponding peak areas 
determined by the LC-MS/MS method (y-axis) were developed for both PC and SPC. Likewise, standard curves for the bioassay were developed with four concentrations and the corresponding inhibition zone but exclusively for SPC. Linearity was evaluated using two replicates for each nisin concentration, in three different days. LC-MS/MS linearity of the response was further studied by plotting residuals against concentrations of standard curves performed for the two types of cheeses. LC-MS/MS specificity was studied by analysing samples of each matrix, to evaluate the possibility for interference of some endogenous compounds. The results vere assessed by checking the presence of interfering substances with the same retention time s $\mathrm{n}$; in $\mathrm{A}$, in comparison to cheese samples fortified with nisin A. The recovery and precisic n reatability and reproducibility) of both, the LC-MS/MS and bioassay method were deterr ineo by spiking experiments where PC and SPC samples were fortified with $0.1,0.5$ and $1, p, 1$ of nisin A before and after the extraction procedure. Precision with limits of acceptar $\cdots_{i 1}^{+}-16 \%$ for CV and 80-110\% for recovery were based on duplicate analysis on three different ¿'ys for each concentration level. Precision was the degree of agreement between indepe $d d^{d} t$ analysis results obtained in different days and was calculated by the standard deviation. of the method's repeatability and reproducibility. Data analyses were performed using the Microsı ${ }^{f t}$ Excel software. The limit of detection (LOD) was calculated as three times the within si $\mathrm{mpl}$ standard deviation for reproducibility $\left(\mathrm{S}_{\mathrm{R}}\right)$ and the limit of quantification (LOQ) was ca culated as 10 times $S_{R}$. Matrix effects (suppression or enhancement of signal due to other substances in the sample) were calculated by comparing slopes for two types of calibration curves. Curve type I, was prepared by spiking extraction solvent with nisin A to reach 0.1, 0.5 and $1 \mathrm{ppm}$. Curve type II, was prepared by spiking cheese samples with nisin A to reach $0.1,0.5$ and $1 \mathrm{ppm}$. Matrix effect was calculated by division of the slope of curve type II with the slope of curve type I. 
2.5 Development and evaluation of growth and growth boundary model for Listeria monocytogenes

\subsubsection{Bacterial strains and pre-culture conditions}

Seven dairy related strains of L. monocytogenes were provided by Arla Foods or Martinez and Rodríguez (2005). The strains were used as a cocktail (Lm-mix including SLU 92, 612, LM 19

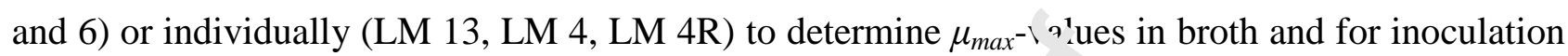
of challenge tests. Strain LM 4R was a spontaneous nisin resistc nt d rivate from LM 4. Each strain was transferred from storage at $-80^{\circ} \mathrm{C}$ to Brain Heart I ifu-ir. (BHI) broth (CM1135, Oxoid, Hampshire, UK) and incubated for $24 \mathrm{~h}$ at $25^{\circ} \mathrm{C}$. Subs que tlly, for broth studies the strains were pre-cultured at $7^{\circ} \mathrm{C}$ or $20^{\circ} \mathrm{C}$ in $\mathrm{BHI}$ broth adjuster. $v$ ith $\mathrm{HCl}$ to $\mathrm{pH} 5.5,6.0$ or 6.5 . For challenge tests the individual strains (SLU 92, 612, Ji: 1; 6) were pre-cultured at a temperature ranging from $8^{\circ} \mathrm{C}$ to $20^{\circ} \mathrm{C}$ in $\mathrm{BHI}$ broth with $1 \% \mathrm{NaCl}$ a.d $\mathrm{pH} 5.5(\mathrm{HCl})$ to simulate conditions in processed cheese. Pre-cultures were grown to a $\mathrm{r}$; ative increase in absorbance $(540 \mathrm{~nm})$ of 0.05 to 0.2 (Novaspec II, Pharmacia Biotech, f, lerøu, Denmark). Lm-mix used in broth and challenge tests was obtained by mixing different wlumes of individually pre-cultured strains depending in the absorbance measurement. The Lm-mix concentration was determined by direct phase contrast microscopy at 1000x magni ication considering that one cell per field of view corresponded to a concentration around $10^{6} \mathrm{cfu} / \mathrm{ml}$ (Adams and Moss, 2016).

\subsubsection{Cardinal parameter term for nisin and expansion of growth and growth boundary model}

The effect of 24 different nisin A concentrations (0-10 ppm nisin, Nisaplin ${ }^{\circledR}$, Danisco, Braband, $\mathrm{DK}$ in $0.02 \mathrm{~N} \mathrm{HCl}$ ) on $\mu_{\max }-$ values of Lm-mix or individual strains were determined in duplicate by automated absorbance measurements at $540 \mathrm{~nm}$ (BioScreen C, Labsystems, Helsinki, 
Finland) at $7^{\circ} \mathrm{C}$ or $20^{\circ} \mathrm{C}$ using $\mathrm{BHI}$ broth adjusted to $\mathrm{pH} 5.5,6.0$ or 6.5 with $\mathrm{HCl}$ and sterilized by filtration (0.2 $\mu \mathrm{m}$, Minisart ${ }^{\circledR}$, Sartorius Stedim Biotech GmbH, Goettingen, Germany). Detection times, defined as the incubation time necessary to observe an increase in absorbance of 0.05 from the lowest absorbance measured in the beginning of incubation were determined for each absorbance growth curve. $\mu_{\max }$-values were determined from absorbance detection times for serially diluted inoculation levels of $10^{2}, 10^{3}, 10^{4}, 10^{5}$ and $10^{6} \mathrm{cfu} / \mathrm{ml}$ as previously described (Dalgaard and Koutsoumanis, 2001). A total of $278 \mu_{\max }$-values of L. r. nocytogenes were determined experimentally in BHI-broth. Nisin MIC-values, $\mu_{r e f *}, \mathrm{n} 1$ and $\mathrm{n} 2$ wer 2 estimated by fitting eq. (2) to square root transformed $\mu_{m a x}$-values obtained for the studied $\mathrm{n}_{\text {. in }}$ concentrations.

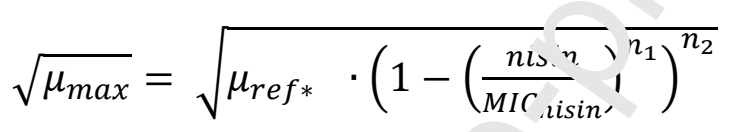

where $\mu_{\max }$ is the maximum specific growth rate $(\mathrm{h})$ and $\mu_{r e f} *$ is the reference maximum specific growth rate for the studied temperature. Whe. fitting eq. (2), n1 was set to 0.5 or 1 and $n 2$ was set to 1 or 2 (Dalgaard, 2009) in order to _esc.ibe data most appropriately and this was determined from root mean square error (RMSE) v.' 'ues. The " $n$ " values are specific for the combination of the microorganism and the inhibitor, ce mpound. A simple equation was used to model and predict the effect of $\mathrm{pH}$ on log-transfor nea. nısin MIC-values, $\log \mathrm{MIC}_{\text {nisin }}=\mathrm{a}+\mathrm{b} * \mathrm{pH}$.

A total of 67 nisin N IC-values, for different L. monocytogenes strains and determined in broth or agar with different $\mathrm{pH}$ values (relevant for processed cheese), were extracted from literature. Four MIC-values were obtained at pH 5.0, 39 MIC-values at pH 5.5 and 24 MIC-values at pH 6.8 for a total of 29 different strains (Ferreira and Lund 1996; Taylor, 2009).

The growth and growth boundary model of Martinez-Rios et al. (2019a) (Supplementary Table 1) previously validated for processed cheese and containing terms for the inhibitory effect of temperature, $\mathrm{a}_{\mathrm{w}}, \mathrm{pH}$, lactic, acetic and citric acids as well as phosphate melting salts was expanded 
with a nisin-term (eq. (2)) to predict growth of L. monocytogenes in processed cheese containing nisin (Eq. S3 in Supplementary Table 4)

\subsubsection{L. monocytogenes growth in processed cheese with added nisin}

To generate data for model development and evaluation, growth of L. monocytogenes in commercial PC and laboratory produced SPC was determined in 15 challenge tests resulting in 45 maximum specific growth rates, lag times and initial and maximน ${ }^{r}>$ cell concentrations at constant temperatures from $3.6^{\circ} \mathrm{C}$ to $19.5^{\circ} \mathrm{C}$.

\subsubsection{Production, inoculation and microbiological ans ysis of processed cheese}

Arla Foods supplied PC cheese formulated vi 11.2 ppm of added nisin A and SPC cheese formulated with $12 \mathrm{ppm}$ of nisin A was pro's $^{\prime}$ ea in the laboratory. SPC was produced by mixing and cooking the ingredients (Supplementary Ta le 2) in a Themomixer (TM5, Vorwerk, USA). The butter was melted at $40^{\circ} \mathrm{C}$ for four mir $\lrcorner t_{s}$ then the water was added and the mixture was blended for four more minutes at $40^{\circ} \mathrm{C}$. Su. sequently, the dry ingredients were added and blended for an additional four minutes at $40^{\circ} \mathrm{C} . \mathrm{s}+$ this point, the $\mathrm{pH}$ of SPC was adjusted (5.4-5.9) with $50 \%$ (w/v) citric acid monohydrate L stly the mixture was blended at $2000 \mathrm{rpm}$ and cooked with different temperature/time profiles (' upplementary Table 3) as recorded by data loggers (TinytagPlus, Gemini Data Loggers Ltd, Chichester, UK). To increase the creaminess of SPC, the mixture was blended at $3100 \mathrm{rpm}$ for $3 \mathrm{~min}$. Both PC and SPC cheeses were inoculated $24 \mathrm{~h}$ after production with $0.1 \%(\mathrm{v} / \mathrm{w})$ of Lm-mix appropriately diluted in chilled saline water $(0.85 \% \mathrm{NaCl})$ to obtain an initial concentration between 1 and $2 \log \mathrm{cfu} / \mathrm{g}$. After inoculation, cheeses were packaged and stored in containers with $50 \pm 1 \mathrm{~g}$ cheese. Storage temperature was recorded by data loggers (TinytagPlus). At each time of sampling, $10 \mathrm{~g}$ of cheese from three different containers were diluted 10-fold with 
chilled physiological saline $(0.85 \% \mathrm{NaCl}$ and $0.10 \%$ Bacto-peptone), homogenized for $30 \mathrm{~s}$ at normal speed in a Stomacher 400 (Seward Medical, London, UK) and then 10-fold serial dilutions were performed. Viable counts of L. monocytogenes were determined by surface plating on PALCAM agar base (CM0877, Oxoid, Hampshire, UK) with PALCAM selective supplement (SR0150, Oxoid, Hampshire, UK) and incubation at $37^{\circ} \mathrm{C}$ for $48 \mathrm{~h}$.

To estimate the kinetic growth parameters for each growth curve the primary integrated and $\log$ transformed logistic model with delay (four parameter model) $\because$ without delay (three parameter model) (eq. (3)); Rosso et al., 1996) was fitted to all individual ‘row th curves of L. monocytogenes obtained in challenge tests at constant temperatures. Fith $\mathrm{d}$ parameter values for initial cell concentration $\left(\log N_{0}, \log \mathrm{cfu} / \mathrm{g}\right)$, lag time $\left(t_{\text {lag }}, \mathrm{h}\right), \mathrm{m} \cdot \mathrm{xim} \mathrm{mm}$ specific growth rate $\left(\mu_{\max }, \mathrm{h}^{-1}\right)$ and

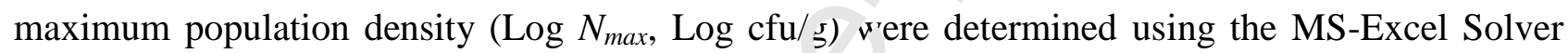
Add-in (Microsoft Corp. Redmond, WA., U`A, L.ta was reported as average \pm standard deviation for each challenge tests. An F-test was used to u. termine if the lag time was significant.

$\log \left(N_{t}\right)=\log \left(N_{0}\right)$

if $t<t_{\text {lag }}$

$\log \left(N_{t}\right)=\log \left(\frac{N_{m}}{1+\left(\left(\frac{N_{\max }}{N_{0}}\right)-1,\right.} \frac{N_{m}}{\exp \left(-\mu_{\max } \cdot\left(t-t_{\text {lag }}\right)\right)}\right)$

if $t \geq t_{\text {lag }}$

where $\mathrm{t}$ is the storage time $(\mathrm{h})$ and $N_{t}$ is the cell concentration $(\mathrm{cfu} / \mathrm{g})$ at time $\mathrm{t}$. Other parameters were indicated above.

\subsubsection{Product characteristics}

Product characteristics of cheeses were determined in triplicate at the start of each challenge test. In addition, $\mathrm{pH}$ was measure every day of microbiological analysis by a PHC725 SN probe (Hach, Brønshøj, Denmark) after $1 \mathrm{~h}$ stirring of $5 \mathrm{~g}$ sample in $25 \mathrm{ml}$ of distilled water. $\mathrm{NaCl}$ was 
quantified by automated potentiometric titration (785 DMP Titrino, Metrohm, Hesisau, Switzerland) and $\mathrm{a}_{\mathrm{w}}$ was measured by a water activity meter (Aqua Lab model CX-2, Decagon devices Inc., Pullman, US). Concentrations of lactic-, acetic- and citric acids were determined by HPLC using external standards for identification and quantification (Østergaard et al., 2014). Concentration of orthophosphate salt was determined by Eurofins (test method QA02S) using ion chromatography. Nisin concentrations were measured by LC-MS/MS (see section 2.2).

\subsubsection{Evaluation of existing predictive models including the eff $t$ t 0 nisin}

Three predictive models including the inhibiting c $^{c}$ fect of nisin were evaluated to assess their ability to predict growth responses of L. monocytoge es in processed cheese containing nisin. The studied models included the models of Boutt if ${ }^{\circ}$ ' et al. (2000), Boziaris and Nychas (2006) and Parente et al. (1998). These models we e $d$-veloped to predict the effect of nisin on survival or growth inhibition of L. monocytogenes in broth and did not consider the distinction between residual and added nisin A. Nevertheless th ese models were evaluate by using the concentrations of added nisin $\mathrm{A}$ and the residual cuncu.trations of nisin $\mathrm{A}$ in the studied cheeses. Evaluation was performed by comparison or prf dicted and observed growth and no-growth responses with calculation of the percenı re : $f$ all samples that were correctly predicted. Incorrect predictions were described as fail-safe (growth predicted when no growth was observed) or as fail-dangerous (no growth predicted when growth was observed).

2.6. New growth and growth boundary model for L. monocytogenes in processed cheese containing nisin

The effect of temperature on lag times of $L$. monocytogenes in processed cheese containing nisin (see section 2.5.3.1.) was assessed by applying the relative lag time (RLT) concept $\left(\mathrm{RLT}=t_{\text {lag }}\right.$ 
$\left.\cdot \mu_{\max } / \operatorname{Ln}(2)\right)$ (Mellefont and Ross, 2003). It was evaluated by using an F-test if RLT-values were constant $\left(R L T=\mathrm{k}_{1}\right)$ or dependent on storage temperature (eq. 4$)$.

$R L T=k_{1}+k_{2} / T^{3}$

In a similar way, it was evaluate if $\log \left(N_{\max }\right)$ was constant $\left(k_{3}\right)$ or dependent on storage temperature (eq. (5))

$\log \left(N_{\max }\right)=k_{3}+k_{4} \cdot \mathrm{T}$

Values of the parameters $\mu_{\text {ref }}$ in eq. (S3), $k_{1}$ and $k_{2}$ (eq (4)' as well as $k_{3}$ and $k_{4}$ (eq. (5)) were estimated by using both a classical two-step predictive nicrobiology approach and a global regression procedure (Hereu et al., 2014; Jewel, 2012) $\boldsymbol{F}^{*}$ the classical two-step approach $\mu_{\text {ref }}$ in eq. (S3) was calibrated using $\mu_{\max }$-values from a' ange tests (Table 4). Calibration allowed finding a $\mu_{\text {ref }}$-value so that the model, rer'ictions corresponded to observed data as well as possible. Likewise, $k_{1}$ and $k_{2}$ in eq. (4) as vell as $k_{3}$ and $k_{4}$ in eq. (5) were independently estimated from $R L T$ - and $\log \left(N_{\max }\right)$-values obcerv ${ }^{2}$ in challenge tests with growth of L. monocytogenes in processed cheese containing nisir. A. Global (one-step) regression was used to determine values of $\mu_{r e f}, k_{1}, k_{2}, k_{3}$ and $k_{4}$ by combini`o ihe growth and growth boundary model (eq. (S3)) with the RLT model (eq. (4)), the $\log \left({ }^{N}{ }_{\max }\right)$ model (eq. (5)) and the primary logistic growth model with delay (eq. (6)). Eq. (6) was fitted in one regression to the entire data set with 45 growth curves and including, respectively, 157 and 417 cell concentrations (log cfu/g) for PC and SPC. Statistical performance of the classical two-step approach and the global regression procedure were compared by calculation of RMSE-values.

$\log \left(N_{t}\right)=\log \left(N_{0}\right)$

if $t<t_{\text {lag }}$ 
$\log \left(N_{t}\right)=\log \left(\frac{10^{k 3+k 4 \cdot T}}{1+\left(\left(\frac{10^{k 3+k 4 \cdot T}}{N_{0}}\right)-1\right) \cdot \exp \left(-\left(\mu_{\max }, E q \cdot(S 3)\right) \cdot\left(t-\left(\frac{\left(k_{1}+k_{2} / T^{3}\right) \cdot \ln (2)}{\mu_{\max }, E q \cdot(S 3)}\right)\right)\right)}\right) \quad$ if $t \geq t_{\text {lag }}$

2.7. Evaluation of new growth and growth boundary model

Performance of the new growth and growth boundary model including the effect of nisin (eq. (S3)) was evaluated by comparing observed and predicted growth and no-growth responses for the 45 growth responses determined in challenge tests with L. mom cytogenes (See 2.5.3). The percentage of correct, fail-safe and fail-dangerous prediction $r$ wre calculated (See 2.5.4). For each experiment with corresponding product characteristics and storage temperature, growth of $L$. monocytogenes was predicted for three scenarios: (a) as uming absence of nisin, (b) using the measured residual nisin concentration and (c) using $h f$ concentration of nisin added to the cheeses at formulation.

\section{Results and discussion}

3.1. Quantification of nisin in cheese by LC-MS/MS and bioassay

A clearly distinguishable peak with retention time of 4.48 min for nisin A was observed (Fig. 1). The LC-MS/MS method showed linear responses for nisin A concentrations ranging from 0.1 to $10 \mathrm{ppm}\left(\mathrm{r}^{2}>0.98\right)$. Residuals of LC-MS/MS responses at different nisin concentrations were randomly distributed, indicating variance homogeneity (Results not shown). The LOD for nisin A in cheese was $0.04 \mathrm{ppm}$, and the LOQ was $0.13 \mathrm{ppm}$. No matrix interference was observed for nisin A detection in the tested cheeses (PC and SPC). Precision was $<16 \%$ and nisin A recoveries from 
the two studied cheeses ranged from 83 to $110 \%$ (Table 2). Recovery of nisin A in SPC tended to increase with nisin concentrations (Table 2).

The bioassay showed linear responses for nisin A concentrations ranging from 0.1 to $1 \mathrm{ppm}$ with a correlation coefficient $r^{2}>0.88$. Residuals were randomly distributed, indicating variance homogeneity (Results not shown). The LOD for nisin A in cheese was $0.07 \mathrm{ppm}$, and the LOQ was 0.25 ppm. Precision was $>16 \%$ and nisin A recoveries from SPC ranged from 53 to $94 \%$ (Table 2).

Clearly, LC-MS/MS measurement of residual nisin A in $\mathrm{p}$ - cessed cheese was reproducible and provided a more precise quantifications of nisin A compare 1 to the studied bioassay. The LCMS/MS method developed in the present study provided rec ov ary values similar to those previously obtained by Ko et al. (2016); however the present study user an extraction solvent without $\mathrm{NaCl}$ as it can interfere with ionization, cause ion suppressir 11 .nd broader peaks in the LC-MS/MS (Sterling et al., 2010). Residual concentrations of nis;. A $_{4}$ 'antified in the present study using LC-MS/MS (0.56-5.28 ppm) were lower than the added cu centrations used in the cheese formulations (11.2$12.0 \mathrm{ppm})$. These differences are in agr se ent with other studies on the stability of nisin in broth or foods after heat treatments (Davie et ai., 1998). For instance, Schneider et al. (2011) found the nisin A concentrations determine.' by LC-MS/MS in processed cheese to be reduced more than 92 $\%$ by a heat treatment at $120 \mathrm{C}$ during $30 \mathrm{~min}$. Ko et al. (2016) also quantified low nisin $\mathrm{A}$ concentrations in processe $r$ heese by LC-MS/MS $(0.34-0.64 \mathrm{mg} / \mathrm{kg})$ but no information on nisin A concentrations recipes were provided.

\subsection{Effect of nisin on growth rates of L. monocytogenes in laboratory media}

The experimentally determined nisin MIC-values at $\mathrm{pH} 5.5$ and at $7^{\circ} \mathrm{C}$ or $20^{\circ} \mathrm{C}$ ranged between $0.55 \pm 0.05 \mathrm{ppm}$ and $3.3 \pm 0.1 \mathrm{ppm}$. At pH 6 and at $20^{\circ} \mathrm{C}$ the nisin MIC-value was $8.8 \pm 1.2$ ppm and at pH 6.5 the values were between $6.4 \pm 1.0$ and $24.9 \pm 3.1$ (Table 3; Fig. 2). Markedly, 
higher MIC-values were determined for L. monocytogenes LM 4R compared to the other strains studied, including its wild type LM4 (Table 3). In order to best fit the $\mu_{m a x}$-values by eq. (2) both n1 and $\mathrm{n} 2$ were found to be 1 for all strains studied. Nisin MIC-values for L. monocytogenes increased significantly $(\mathrm{p}<0.05)$ with increase of $\mathrm{pH}$ and this was observed for data from the present study as well as for data from the scientific literature (Fig. 3). To predict MIC-values of nisin depending on pH a nisin MIC-term based on a simple regression model was developed (eq. 7)

$$
\log \left(M I C_{\text {nisin }}, p p m\right)=-(3.08 \pm 0.32)+\left(0.64 \pm 0.05 \cdot \eta H \quad R^{2}=0.65\right.
$$

Several studies found nisin to be more effe :ty/e in acidic environments (Khan et al., 2015; Thomas and Wimpenny, 1996) and this is $1 \mathrm{t}$ as eement with eq. (7). This simple model was developed including both experimental and lite. ature nisin A MIC-values and reflected variability among 29 L. monocytogenes strains; ar a $\mathrm{r}$ ?t also previously discussed by Katla et al. (2003). This simple model (eq. (7)), can estima n nisin A MIC-values for products with $\mathrm{pH}$ values outside the average values (5.4-6.0) for proct sed cheese and therefore support new formulations with altered $\mathrm{pH}$ values. Furthermore it ، an $s$ upport the development of other foods products with added nisin $\mathrm{A}$ such as dairy, meat and f: products with higher $\mathrm{pH}$ than processed cheese (Davies et al., 1997; Nilsson et al., 1997; Oshima et al., 2014; Ruiz et al., 2009; Schillinger et al., 2001). Importantly, this simple model predicts with reasonable precision (RMSE of 0.54) the MIC-values of nisin A (32-37 ppm) at $\mathrm{pH}$ 7.2-7.3 when compared to $53 \mathrm{MIC}$-values (average of $17 \mathrm{ppm}$ ) extracted from the literature for various isolates of L. monocytogenes (Campion et al., 2013; Hara et al., 2009; Martínez and Rodríguez, 2005; Neetoo et al., 2008; Popowska et al., 2006; Smith et al., 2016; Taylor et al., 2009). 


\subsection{Product characteristics of processed cheese and L. monocytogenes growth kinetics}

Commercial PC and laboratory produced SPC showed some variation in initial pH (5.4-6.1) and $\mathrm{a}_{\mathrm{w}}(0.970-0.983)$ (Table 4). More variability was observed for water phase concentrations of lactic acid (869-9869 ppm), acetic acid (<LOD-2384 ppm), citric acid (3766-20864 ppm) and concentration of orthophosphate $(0.8-2.00 \%)$. The variability observed in residual nisin A concentrations among challenge test (CT7-15) (Table 4) was $\mathrm{ex}_{\mathrm{r}}{ }^{\circ}$ cted as a result of the different heat treatments used during preparation (Supplementary Table 3 ,

L. monocytogenes grew in both $\mathrm{PC}$ and SPC fror. 7 to $20^{\circ} \mathrm{C}$, and $\mu_{\max }$-values were influenced by storage conditions and product cha'acte istics (Table 4). Residual nisin A concentrations and $\mathrm{pH}$ had a pronounced effect on $\boldsymbol{L}$ monocytogenes $\mu_{\max }$-values, as suggested by eq. (6). This is for example seen from the ch in ng. tests 7 to 12 , which were all formulated with 12 ppm nisin A. However, due to its heat treatı `nt, challenge test 10 had lowest residual nisin A concentration $(0.88 \mathrm{ppm})$ and also his $\mathrm{n}_{\mathrm{L}^{+}} \mathrm{pH}$ of 5.9 and this resulted a $\mu_{\max }$-value of $0.023 \mathrm{~h}^{-1}$ compared to $0.000 \mathrm{~h}^{-1}$ for the othe chanienge tests (Table 4). The observed long lag times at low temperatures for processed cheesı containing nisin were in agreement with previous studies where researchers reported extend d $\mathrm{d}$ la ? times for L. monocytogenes and other microorganisms in products containing nisin (Davies et ·.., 1997; Nilsson et al., 1997; Oshima et al., 2014; Ruiz et al., 2009; Schillinger et al., 2001). For example, Davies et al. (1997) showed that the incorporation of $2.5 \mathrm{ppm}$ of nisin $\mathrm{A}$ in ricotta-cheese after production extended the lag times of $L$. monocytogenes by 44 days compared with the same product supplemented with $1.25 \mathrm{ppm}$ when stored between $6-8^{\circ} \mathrm{C}$. In the same way, nisin A was found to extend the lag times of L. monocytogenes in tofu stored at $10^{\circ} \mathrm{C}$ (Schillinger et al., 2001). 
3.4. Evaluation of available predictive models including the growth inhibiting effect of nisin A

The effect of nisin on growth of L. monocytogenes in combination with other environmental factors including temperature, $\mathrm{pH}$ and $\mathrm{NaCl} / \mathrm{a}_{\mathrm{w}}$ has previously been studied in broth and predictive models were suggested by Bouttefroy et al. (2000), Boziaris and Nychas (2006) and Parente et al. (1998). These models did not consider the distinction between residual and added nisin and they were not previously evaluated for their ability to predict growth responses of L. monocytogenes in foods containing nisin. Interestingly, the performance of two $\mathrm{o}^{*}$ of the three models improved when residual nisin A concentrations rather than added nisin A con entrations in processed cheese (Table 5) were used as model input together with other mea $\mathrm{u}_{\mathbf{1}}>\mathrm{d}$ product characteristics and storage conditions (Table 4). Most notable, the percentage of orr ct predictions increased from $14 \%$ to $100 \%$ for the model of Boziaris and Nychas (2006, w hen nisin A concentrations measured by LCMS/MS were used as model inputs rather tha . . da $\mathrm{d}$ nisin A concentrations (Table 5). These results suggest residual nisin A concentrations may be . nore useful than added nisin A concentrations when the objective is to predict the growth re $\mathrm{p}$, nses of $L$. monocytogenes in processed cheese containing $\operatorname{nisin} \mathrm{A}$.

3.6. Modelling growth of $L$. mor ocytogenes in processed cheese containing nisin

RLT-values signifirar tly $(\mathrm{p}<0.05)$ increased at low storage temperatures and this effect was appropriately described by eq. (4) (Fig. 4). In contrast, storage temperature had no significant effect $(\mathrm{p}>0.05)$ on $\log \left(N_{\max }\right)$.

The model of Martinez-Rios et al. (2019a) was expanded with a nisin term that included $M I C_{n i s i n}$-values as described by eq. (7). For this new growth and growth boundary model (eq. (S3)), the $\mu_{r e f}$-value of 0.419 in the original model, increased markedly (Table 6) when the model was calibrated to describe the data for growth of L. monocytogenes in processed cheese containing nisin 


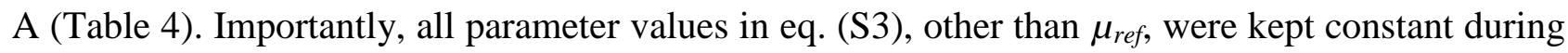
this product calibration of the growth and growth boundary model. The global (one-step) regression approach described the growth data $(\log \mathrm{cfu} / \mathrm{g})$ slightly better than the two-step approach and resulted in the highest calibrated $\mu_{r e f}$-value of 0.629 (Table 6).

The long lag times (Table 4) and corresponding high RLT-values at low storage temperatures (Fig. 4; Fig 5b) observed together with increased growth rates $\left(\mu_{\text {ref }}\right.$-value; Table 6$)$ of L. monocytogenes growing in processed cheese containing nisin 1 are in agreement with previous studies. In fact, increased of $\mu_{\max }$-values in different foods vere reported when the pathogen resumed growth after extended lag times (Davies et al., :5,7. Nilsson et al., 1997; Ruiz et al., 2009). As shown in Figure 5b, the model of Martinez-P os e al. (2019a) was unable to describe the RLT-values observed at low temperatures in challe ، - tests (Table 4). However, combining simple models for the effect of $\mathrm{pH}$ on $M I C_{n i s i n}$-valu ${ }_{-}\left(\mathrm{e}_{4}(7)\right)$ and for the effect of temperature on RLTvalues (eq. (4)) with an extensive growth and y. . wth boundary model (eq. S3) allowed this growth pattern to be described (Table 6) as sho $N 1$ : $n$ Figure $5 \mathrm{~b}$.

\subsection{Evaluation of the new growth and growth boundary model}

The new growth ar $\mathrm{d}$ g owth boundary model (eq. S3) correctly predicted $100 \%$ of the growth or no growth resno ises for L. monocytogenes in processed cheese with nisin A. This positive result was obtained when using residual nisin A concentrations, determined by the developed LC-MS/MS method, as model input (Table 7). It is interesting that the same model was less performant both when nisin A concentrations added to products and when no nisin were used as model input together with other measured product characteristics and storage conditions (Table 4, Table 7). This supports the approach of the present study that accurate measurement of residual nisin A concentrations is important to predict growth of L. monocytogenes in foods that contain 
nisin. Furthermore, these results represent a successful product validation of the new growth boundary model (eq. (S3)) for processed cheese with nisin A. However, when used to predict growth of L. monocytogenes in processed cheese with nisin, further evaluation of this model with additional data is needed. This is the case as model parameters related to lag time and growth rates were calibrated to data in Table 4, and these data therefore cannot be used to evaluate and validated the same model. The range of applicability, where the new model has been successfully validated for prediction of growth and no-growth responses include proce ad cheese with residual nisin A concentration of from $0.56 \mathrm{ppm}$ to $5.28 \mathrm{ppm}$ together with othe1 oro luct characteristics and storage condition as shown in Table 4.

$86 \%$ correct and $14 \%$ fail-safe predictions of gr wth or no-growth responses were obtained by assuming no added nisin $\mathrm{A}$ in challenge tests $\left({ }_{1 \mathrm{a}}, \mathrm{l}\right.$ e 7$)$. These predictions correspond to using the model of Martinez-Rios et al. (2019a) th ^ lo not include a nisin term (eq. (S1)). This model however, include terms for the melting salts $₫$-phosphate (P2) and tri-phosphate (P3) and these terms may be included in the new gr or $h$ and growth boundary model to expand its range of applicability to processed cheese c- ntaning mixtures of different phosphate melting salts. As the developed nisin A term (eq. (7)) , asonably predicted $M I C_{\text {nisin }}$-values at $\mathrm{pH}$ as high as 7.2-7.3 (see section 3.3) it is also likely that the new model can be validated above the $\mathrm{pH}$ of 5.4-6.1 currently studied for processed cheese (Table 4). The logit model of Boziaris and Nychas (2006), including the effect of temperature, $\mathrm{a}_{\mathrm{w}}, \mathrm{pH}$ and nisin, also correctly predicted $100 \%$ of the observed growth and no-growth responses (Table 5). Compared to that model, the new model has the advantage of including the effect of more environmental factors relevant for processed cheese such as orthophosphate salt and organic acids as discuss below. $\Psi$ is a quantitative measurement for the distance between specific environmental conditions and the growth boundary of L. monocytogenes $(\psi=1)$ (see Supplementary Table 5 for details about calculation of the $\psi$-value). Compared with logit 
models were a probability response of growth/no-growth is obtained; the new model provides a mathematical value $(\psi)$ representing how far the develop formulation is from the growth boundary of L. monocytogenes. The new model (Eq. (S3)) included the combined effect of eight environmental factors on the growth boundary of L. monocytogenes in processed cheese. As previously described and discussed in several studies such extensive models can be developed by variations of the cardinal parameter approach, which is much less data demanding than for example polynominal models or logistic regression (logit) models. W'e to their demand for data, polynominal and logit models most often are limited to include 1 e $\mathrm{c}$ mbined effect of between 4 to 7 environmental factors even when studied in liquid labor tc $y$ nedia and the calibration of these model for specific food remains a challenge (Dalgaard ind Mejlholm, 2019; Le Marc et al., 2002; Ross and Dalgaard, 2004; Razavilar and Genigeorg.s, 1998).

The developed extensive growth bour is "y nodel (Eq. (S3)) included the combined effect of eight environmental factors which will fac."itate its use for product development and reformulation. As an example if a proce, st 1 rneese is contaminated by a consumer after opening a package, the new growth and growt: boundary model will predict growth of $L$. monocytogenes with a $\psi$-value of 0.4 at $5{ }^{\circ} \mathrm{C}$ when the cheese contain $1.0 \mathrm{ppm}$ of residual nisin $\mathrm{A}, \mathrm{pH} 6.0, \mathrm{a}_{\mathrm{w}}$ of 0.980 and water phase concentra ion: of lactic acid (4,000 ppm), acetic acid (1,000 ppm), citric acid $(10,000 \mathrm{ppm})$ and orthophos phate $(0.8 \%)$. By lowering the $\mathrm{pH}$ of this product to 5.75 with water phase concentrations of lactic acid (6,000 ppm) and acetic acid (2,000 ppm), L. monocytogenes will be predicted to be at its growth boundary with a $\psi$-value of 1.0. However, if the residual nisin $\mathrm{A}$ concentration in the processed cheese with $\mathrm{pH} 5.75$ is increased from 1.0 to $2.5 \mathrm{ppm}$ then the predicted $\psi$-value will become 2.2 and the product will be stabilized against growth of $L$. monocytogenes during the open shelf-life with a solid margin to its growth boundary (Dalgaard and Mejlholm, 2019). Clearly, practical application of the new growth and growth boundary model to 
support product development and re-formulation of processed cheeses, stabilized against growth of L. monocytogenes, during the open shelf-life requires information about product characteristics. Residual nisin A concentrations in processed cheese can be measured by LC-MS/MS (see 3.1) and further information about added nisin A in formulations, applied heat processing and stability of nisin A during storage is likely to be required to obtain desired levels of residual nisin A (Supplementary Table 3). In conclusion, the present study quantified and modelled the effect of $\mathrm{pH}$ on nisin A MIC-values for L. monocytogenes and included the eff $-t$ in a cardinal parameter growth and growth boundary model that can predict the effect of $r$ 'sidı al nisin A concentrations on growth/no-growth responses in cheese. The new cardinal $\mathrm{a}_{\mathbf{n}} \mathrm{n}$ iter growth and growth boundary model is useful to predict growth/no-growth and con que itly can support product development when used together with LC-MS/MS to determine it idual nisin A concentrations. Further studies to determine the precision and range of ${ }^{\mathrm{rt}} \mathrm{P}_{\mathrm{ic}}$ hility for the growth part of the new growth boundary model is desirable.

\section{Acknowledgements}

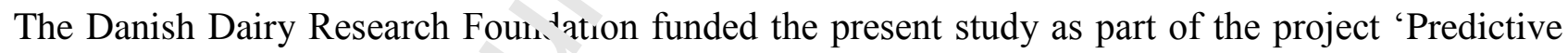
food microbiology tool fo ris : assessment and documentation of food safety'. We thanks Dr. Beatriz Martinez Fernández and Dr. Ana Rodríguez González from the Instituto de Productos Lácteos de Asturias (IPLA-CSIC) for providing L. monocytogenes strains LM4 and LM4R. We also thank Trine Bundesen from DuPont for providing Nisaplin ${ }^{\circledR}$. Lastly, we thank laboratory technicians Rannvá Høhnadóttir Houmann, Else Petrine Celie Berthelsen and Peter Kristian Kristoffersen for their assistance with challenge tests and development of the nisin bioassay.

\section{References}


Adams, M.R., Moss, M.O., McClure, P.J., 2016. Methods for the microbiological examination of foods. In: Food Microbiology. The Royal Society of Chemistry, Croydon, UK, pp. 413-446.

Benkerroum, N., Sandine, W.E., 1988. Inhibitory action of nisin against Listeria monocytogenes. J. Dairy Sci. 71, 3237-3245. https://doi.org/10.3168/jds.S0022-0302(88)79929-4

Boziaris, I.S., Nychas, G.J.E., 2006. Effect of nisin on growth boundaries of Listeria monocytogenes Scott $\mathrm{A}$, at various temperatures, $\mathrm{pH}$ and water activities. Food Microbiol. 23, 779-784. https://doi.org/10.1016/j.fm.2006.03.003

Bouttefroy, A., Mansour, M., Linder, M., Milliere, J-B., 2000. Inı ihitory combinations of nisin, sodium chloride, and $\mathrm{pH}$ on Listeria monocytogenes ATCC $15: 13$ in broth by an experimental design approach. Int. J. Food Microbiol. 54, 10 -1:5. https://doi.org/10.1016/S0168$\underline{1605(99) 00171-3}$

Campion, A., Casey, P.G., Field, D., Cotter, P.D., Hi. C. Ross, R.P., 2013. In vivo activity of nisin A and nisin V against Listeria monocytogene, in 1, ice. BMC Microbiol. 13:23.

Cotter, P.D., Hill, C., Ross, R.P., 2005. Bacteri sclı. developing innate immunity for food. Nat. Rev. Microbiol. 3, 777-788. https://doi org ' $10 . i 038 / \mathrm{nrmicro1273}$

Dalgaard, P., 2009. Modelling of micrc'ial growth. Bulletin of the International Dairy Federation 433, 45-60.

Dalgaard, P., Koutsoumanis, K., 2. 001. Comparison of maximum specific growth rates and lag times estimated from absork ince and viable count data by different mathematical models. J. Microbiol. Methods. 43, 18 J 1५ó. https://doi.org/10.1016/S0167-7012(00)00219-0

Dalgaard, P., Mejlholm O , 2 19. Modelling growth of Listeria and lactic acid bacteria in food environments. In: Brı 'ier, A., (Ed.), Foodborne bacterial pathogenes, Springer, New York, USA, 247-264.

Davies, E.A., Bevis, H.E., Potter, R., Harris, J., Williams, G.C., Delves-Broughton, J., 1998. The effect of $\mathrm{pH}$ on the stability of nisin solution during autoclaving. Lett. Apply. Microbiol. 27, 186-187.

Davies, E.A., Bevis, H.E., Delves-Broughton, J., 1997. The use of the bacteriocin nisin, as a preservative in ricotta-type cheeses to control the food-borne pathogen Listeria monocytogenes. Lett. Apply. Microbiol. 24, 343-346.

Delves-Broughton, J., 2008. Use of the natural food preservatives, nisin and natamycin, to reduce detrimental thermal impact on product quality. In: Richardson, P. (Ed.), In-pack processed foods: Improving quality. Woodhead Publishing, Sawston, UK, pp. 319-337. 
https://doi.org/10.1533/9781845694692.4.319

FDA , 1988. Nisin preparation: Affirmation of GRAS status as a direct human food ingredient. Food and Drug Administration (Federal Register April 6, 1988), 53, 11247.

Ferreira, M.A.S.S., Lund, B.M., 1996. The effect of nisin on Listeria monocytogenes in culture medium and long-life cottage cheese. Lett. Appl. Microbiol. 22, 433-438. https://doi.org/10.1111/j.1472-765X.1996.tb01197.x

Fowler, G.G., Jarvis, B., Tramer, J., 1975. The assay of nisin in foods. In: Board, R.G., Lovelock, D.W. (Eds.), Some Methods for Microbiological Assay. Academic Press, New York, pp. 91105.

Fuselli, F., Guarino, C., La Mantia, A., Longo, L., Faberi, f., Narianella, R.M., 2012. Multidetection of preservatives in cheeses by liquid chromat, gl nny-tandem mass spectrometry. J. Chromatogr. B Anal. Technol. Biomed. Life Sci. 906, 1-1 https://doi.org/10.1016/j.jchromb.2012.07.035

Glass, K., A., Mu, M., LeVine., B., Rossi, F., 21 1\%. .uhibition of Clostridium botulinum in model reduced-sodium pasteurized preparer. c leese products. J. Food Prot. 80, 1478-1488. https://doi.org/10.4315/0362-028X.JFP-1 ${ }^{\prime}$-027

Hara, H., Ohashi, Y., Sakurai, T., Yagi Y , Iujisawa, T., Igimi, S., 2008. Effect of nisin (Nisaplin) on the growth of Listeria monocvtor er es in karashi-mentaiko (red-pepper seasoned cod roe). J. Food hyg. Soc. Japan, 4 173-1:7.

Hereu, A., Dalgaard, P., Garriga, M., Aymerich, T., Bover-Cid, S., 2014. Analysing and modelling the growth behaviour of Lintria monocytogenes on RTE cooked meat products after a high pressure treatment $+40 \mathrm{~N}$ Pa. Int. J. Food Microbiol. 186, 84-94.

https://doi.org/10.1010, ijfoodmicro.2014.06.020

ISO, 2009. Cheese - Determination of nisin A content by LC-MS and LC-MS-MS. ISO/TS 27106 IDF/RM 217 2002, 1-14.

Jewell, K., 2012. Comparison of 1-step and 2-step methods of fitting microbiological models. Int. J. Food Microbiol. 160, 145-161.

Katla, T., Naterstad, K., Vancanneyt, M., Swings, J., Axelsson, L., 2003. Differences in susceptability of Listeria moonocytogenes strains to sakacin P., sakacin A, pediocin PA-1 and nisin. Appl. Environ. Microbiol. 4431-4437. https://doi.org/10.1128/AEM.69.8.4431$\underline{4437.2003}$

Khan, A., Vu, K.D., Riedl, B., Lacroix, M., 2015. Optimization of the antimicrobial activity of 
nisin, Na-EDTA and pH against gram-negative and gram-positive bacteria. LWT - Food Sci. Technol. 61, 124-129. https://doi.org/10.1016/j.lwt.2014.11.035

Ko, K.Y., Park, S.R., Lim, H.S., Park, S.J., Kim, M., 2016. Improved pretreatment method for determination of nisins $\mathrm{A}$ and $\mathrm{Z}$ and monitoring in cheese using liquid chromatrographytandem mass spectrometry. Food Anal. Methods 9, 122-130. https://doi.org/10.1007/s12161$\underline{015-0158-\mathrm{y}}$

Le Marc Y., Huchet V., Bourgeois C.M., Guyonnet J.P., Mafart P., Thuault D., 2002. Modelling the growth kinetics of Listeria as a function of temperature, $\mathrm{pH}$ and organic acid concentration. Int J Food Microbiol 73:219-237. https://doi.org/10.1016/S0168-1605(01)00640-7

Martinez-Rios, V., Gkogka, E., Dalgaard, P., 2019a. New term to rua-tify the effect of temperature on $\mathrm{pH}_{\mathrm{min}}$-values used in cardinal parameter growth $\mathrm{mc}$ tels for Listeria monocytogenes. Frontiers in Microbiology, 84, 103255. https://doi.org/10 .33i 9/fmicb.2019.01510

Martinez-Rios, V., Jørgensen, M.Ø., Koukou, I., Gkor, ․, Dalgaard, P., 2019b. Growth and growth boundary model with terms for melting sáts ${ }^{\dagger} J$ predict growth responses of Listeria monocytogenes in spreadable processed cheese Fuod Microbiol., 10, 1510.

https://doi.org/10.1016/j.fm.2019.103255

Martínez, B., Rodríguez, A., 2005. Ar im crobial susceptibility of nisin resistant Listeria monocytogenes of dairy origin. FEMS Microbiol. Lett. 252, 67-72. https://doi.org/10.1016/j.femsle.2005. ${ }^{19.025}$

Neetoo, H., Ye, M., Chen, H., $2008{ }^{D_{0}}{ }^{\cdots}$ tial antimicrobials to control Listeria monocytogenes in vacuum-packaged cold-smokeu salmon pâté and fillets. Int. J. Food Microbiol. 123, 220-227. https://doi.org/10.1016/j.ijfnocinicro.2008.02.001

Nilsson, L., Huss, H.H., G an?, L., 1997. Inhibition of Listeria monocytogenes on cold-smoked salmon by nisin anc `a ' $\urcorner n$ r. dioxide atmosphere. Int. J. Food. Microbiol. 38, 217-227.

NMKL, 2009. Validation or chemical analytical methods (NMKL Procedure No. 4, 2009).

Østergaard, N.B., Eklöw, A., Dalgaard, P., 2014. Modelling the effect of lactic acid bacteria from starter- and aroma culture on growth of Listeria monocytogenes in cottage cheese. Int. J. Food Microbiol. 188, 15-25. https://doi.org/10.1016/j.ijfoodmicro.2014.07.012

Oshima, S., Hirano, A., Kamikado, H., Nishimura, J., Kawai, Y., Saito, T., 2014. Nisin A extends the shelf life of high-fat chilled dairy dessert, a milk-based pudding. J. Appl. Microbiol. 116, 1218-1228. https://doi.org/10.1111/jam.12454

Papagianni, M., Avramidis, N., Filioussis, G., Dasiou, D., Ambrosiadis, I., 2006. Determination of bacteriocin activity with bioaddays carried out on solid and liquid substrated: assessing the factor "indicator microorganism". Microb. Cell Fact. 5, 1-14. https://doi.org/10.1186/1475- 
$\underline{2859-5-30 .}$

Parente, E., Giglio, M.A., Ricciardi, A., Clementi, F., 1998. The combined effect of nisin, leucocin $\mathrm{F} 10, \mathrm{pH}, \mathrm{NaCl}$, EDTA on the survival of Listeria monocytogenes in broth. Int. J. Food Microbiol. 40, 65-75.https://doi.org/10.1016/S0168-1605(98)00021-X

Pongtharangkul, T., Demirci, A., 2004. Evaluation of agar diffusion bioassay for nisin quantification. Appl. Microbiol. Biotechnol. 65, 268-272.

Popowska, M., Olszak, M., Markiewicz, Z., 2006. Susceptability of Listeria monocytogenes strains isolated from dairy products and frozen vegetables to antibiotics inhibiting murein synthesis and to disinfectants. Polish J. Microbiol. 4, 279-288.

Razavilar, V. and Genigeorgis, C., 1998. Prediction of Listeria spp. growth as affected by various levels of chemicals, $\mathrm{pH}$, temperatures and storage tinc in a model broth. Int. J. Food

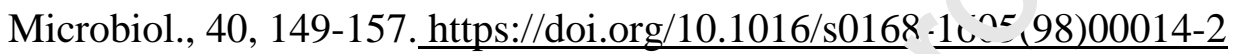

Redmond, E.C., Griffith, C.J., 2003. Consumer food ha. flin g in the home: A review of food safety studies. J. Food Prot. 66, 130-161. https://doi.org/1º.4, 15/0362-028X-66.1.130.

Ross, T., 1996. Indices for performance evaluat on us predictive models in food microbiology. J. Appl. Bacteriol. 81, 501-508.

Ross and Dalgaard, 2004. Chapter 3. Secondary Models. In: McKellar, R.C., Lu, X (Ed.), Modelling microbial responses in $f$, . $d$. SRC Press, Boca Raton, pp. 110-119.

Rogers, A.M., Montville, T.J., 1991. In 'nroved agar diffusion assay for nisin quantification. Food Biotechnol. 5, 161-168.

Rosso, L., Bajard, S., Flandro1s, I.'.,, Lahellec, C., Fournaud, J., Veit, P., 1996. Differential growth of Listeria monocytog 'nes at 4 and $8^{\circ} \mathrm{C}$ : Consequences for the shelf life of chilled products. Journal of Food Prou -tlu. 59, 944-949. https://doi.org/10.4315/0362-028X-59.9.944

Ruiz, A., Williams, S.K., vjeri, N., Hinton, A., Rodrick, G.E., 2010. Nisin affects the growth of Listeria monocytogenes on ready-to-eat turkey ham stored at four degrees Celsius for sixtythree days. Poultry Science, 89, 353-358. https://doi.org/10.3382/ps.2008-00503

Schillinger, U., Becker, B., Vignolo, G., Holzapfel, W.H., 2001. Efficacy of nisin in combination with protective cultures against Listeria monocytogenes Scott A in tofu. Int. J. Food Microbiol. 71, 159-168. https://doi.org/10.1016/S0168-1605(01)00612-2

Schneider, N., Werkmeister, K., Pischetsrieder, M., 2011. Analysis of nisin A, nisin Z and their degradation products by LCMS/MS. Food Chem. 127, 847-854.

https://doi.org/10.1016/j.foodchem.2011.01.023

Smith, M.L., Draper, L., Hazelhoff, P-J., Cotter, P.D., Ross, R.P., Hill, C., 2016. A bioengineered 
nisin derivate, M21A, in combination with food grade additives eradicates biofilms of Listeria monocytogenes. Front. Microbiol. 7, 1939. https://doi.org/10.3389/fmicb.2016.01939

Sterling, H.J., Batchelor, J.D., Wemmer, D.E., Williams, E.R., 2010. Effects of buffer loading for electrospray ionization mass spectrometry of a noncovalent protein complex that requires high concentrations of essential salts. J. Am. Soc. Mass Spectrom. 21, 1045-1049. https://doi.org/ doi:10.1016/j.jasms.2010.02.003.

Taylor, T.M., 2009. Efficacy of novel food antimicrobial combinations for control of Listeria monocytogenes for preservation of ready-to-eat (RTE) products. Research Report, Deparment of Animal Science, Texas A\&M. https://www.pork.org/research/efficacy-of-novel-foodantimicrobial-combinations-for-control-of-listeria-monocytog nes-for-preservation-of-readyto-eat-rte-products/ (accessed 07.12.18).

Thomas, L.V., Delves-Broughton, J., 2005. Nisin. In: Davi ısoı P.M., Sofos, J.N., Branen, A.L. (Eds.), Antimicrobials in foods. CRC, Taylor \& Franc: Givup, Boca Raton, pp. 237-274.

Thomas, L. V, Wimpenny, J.W.T., 1996. Investigatio. $\mathrm{n}^{t}$ the effect of combined variations in temperature, $\mathrm{pH}$, and $\mathrm{NaCl}$ concentration on nicin inhıbition of Listeria monocytogenes and Staphylococcus aureus. Appl. Environ. Micro i sl. 52, 2006-2012.

Tramer, J., Fowler, G.G., 1964. Estimatic 1 o nisin in foods. J. Sci. Food Agric. 15, 522-528. https://doi.org/http://0-dx.doi.org.lib.exett. ac.uk/10.1111/j.1530-0277.2009.00957.x 


\section{Journal Pre-proof}

Table 1. Comparison of LC-MS/MS protocols from the present study and from ISO (2009).

\begin{tabular}{lll}
\hline & Present study & ISO (2009) \\
\hline Equipment & UHPLC (Dionex Thermo scientific) & LC-MS/MS \\
& EVOQ EliteTM triple quadrupole MS(Bruker) & \\
Column & Zorbax 300 SB-C18 $(2.1 \times 50 \mathrm{~mm})$ & PLRP-S (2.1 x 150 mm) \\
& $($ Agilent Technologies) & (Polymer Lab Ltd.) \\
Extraction solvent & $0.1 \%$ formic acid, methanol/water (1:1), pH 2.0 & Formic acid/water (1:200) \\
& with HCL & \\
Parent ion & 839 & 672 \\
Fragment ions & 1081,811 & 0 \\
\end{tabular}




\section{Journal Pre-proof}

Table 2. Recovery and precision for determination of nisin A by LC-MS/MS and bioassay.

\begin{tabular}{|c|c|c|c|c|}
\hline Method & Matrix & $\begin{array}{c}\text { Conc. of } \\
\text { nisin A (ppm) }\end{array}$ & Recovery (\%) & $\mathrm{CV}(\%)$ \\
\hline \multirow{6}{*}{ LC-MS/MS } & \multirow{3}{*}{ Processed cheese (PC) } & 0.1 & 99 & 13 \\
\hline & & 0.5 & 108 & 2 \\
\hline & & 1 & 110 & 4 \\
\hline & \multirow{3}{*}{ Spreadable processed cheese (SPC) } & 0.1 & 83 & 14 \\
\hline & & 0.5 & 95 & 11 \\
\hline & & 1 & 100 & 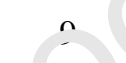 \\
\hline \multirow{3}{*}{ Bioassay } & \multirow{3}{*}{ Spreadable processed cheese (SPC) } & 0.1 & $53^{\mathrm{a}}$ & $\overline{1} 6^{\mathrm{a}}$ \\
\hline & & 0.5 & 94 & $35^{\mathrm{a}}$ \\
\hline & & 1 & & $33^{\mathrm{a}}$ \\
\hline
\end{tabular}

${ }^{\mathrm{a}}$ Result outside acceptability range being: $\mathrm{CV}<16 \%$ and recovery within 80 - $2 \%$ 


\section{Journal Pre-proof}

Table 3. Experimentally determined minimum inhibitory concentration (MIC) values of nisin A for different L. monocytogenes strains

\begin{tabular}{|c|c|c|c|c|c|}
\hline Strain & $\mathrm{pH}$ & Temp. $\left({ }^{\circ} \mathrm{C}\right)$ & $\begin{array}{c}\mu_{r e f^{*}, \mathrm{~h}^{-1}} \\
(\mathrm{AVG} \pm \mathrm{SE})\end{array}$ & $\begin{array}{c}\mathrm{MIC}, \mathrm{ppm} \\
(\mathrm{AVG} \pm \mathrm{SE})\end{array}$ & $\begin{array}{c}\text { Duration of } \\
\text { experiments (days) }\end{array}$ \\
\hline LM 4 & 6.5 & 7 & $0.205 \pm 0.01$ & $4.9 \pm 0.4$ & 20 \\
\hline $\mathrm{LM} 4 \mathrm{R}$ & 6.5 & 7 & $0.081 \pm 0.00$ & $24.9 \pm 3.1$ & 14 \\
\hline LM13 & 6.5 & 7 & $0.193 \pm 0.01$ & $8.1 \pm 0.7$ & 14 \\
\hline$L m-m i x^{a}$ & 6.5 & 7 & $0.225 \pm 0.00$ & $9.1 \pm 0.3$ & 5 \\
\hline LM4R & 6.5 & 20 & $0.406 \pm 0.01$ & $27.0 \pm 3.4$ & 3 \\
\hline 6 & 6.5 & 20 & $0.455 \pm 0.02$ & $6.4 \pm 1.0$ & 13 \\
\hline LM13 & 6.5 & 20 & $0.474 \pm 0.01$ & $14.1 \pm 0.9$ & 20 \\
\hline$L m-m i x^{a}$ & 6.5 & 20 & $0.527 \pm 0.01$ & $15.5 \pm 0.6$ & 14 \\
\hline$L m-m i x^{\mathrm{a}}$ & 6.0 & 20 & $0.431 \pm 0.01$ & $8.8 \pm 1.2$ & 4 \\
\hline $\mathrm{LM} 4 \mathrm{R}$ & 5.5 & 20 & $0.353 \pm 0.01$ & $3.3 \pm 0.1$ & Is \\
\hline 612 & 5.5 & 7 & $0.138 \pm 0.00$ & $0.55 \pm 095$ & 64 \\
\hline 612 & 5.5 & 20 & $0.417 \pm 0.02$ & $0.75+\therefore 04$ & 13 \\
\hline$L m-m i x^{\mathrm{a}}$ & 5.5 & 20 & $0.415 \pm 0.02$ & $r_{. .}, 5 \pm 0 . r_{0}$ & 11 \\
\hline
\end{tabular}

${ }^{\mathrm{a}}$ The cocktail Lm-mix included the isolates SLU 92, 612, LI $\overline{1} \overline{19} \overline{\text { nnd }} \overline{6 .}$ 
Journal Pre-proof

Table 4. Storage conditions, product characteristics and estimated growth parameters from fitting the logistic model with delay (eq. (3)) to the L. monocytogenes counts on processed cheese obtained from challenge tests.

\begin{tabular}{|c|c|c|c|c|c|c|c|c|c|c|c|c|c|c|}
\hline \multirow{3}{*}{$\underset{\mathrm{b}}{\mathrm{CT}}$} & \multirow{3}{*}{$\underset{\mathrm{c}}{\mathrm{N}}$} & \multirow{3}{*}{$\begin{array}{c}\text { Storage } \\
\text { Temp. } \\
\left({ }^{\circ} \mathrm{C}\right)\end{array}$} & \multicolumn{7}{|c|}{ Product characteristics $(A v g . \pm S D)^{a}$} & \multicolumn{5}{|c|}{ Growth parameter values (Avg. $\pm \mathrm{SD})^{\mathrm{a}}$} \\
\hline & & & \multirow{2}{*}{$\mathrm{pH}$} & \multirow{2}{*}{$\mathrm{a}_{\mathrm{w}}$} & \multicolumn{3}{|c|}{ Organic acids in water phase (ppm) } & \multirow{2}{*}{$\begin{array}{l}\mathrm{P} 1^{\mathrm{d}} \text { in } \\
\text { water } \\
\text { phase } \\
(\%)^{\mathrm{d}}\end{array}$} & \multirow{2}{*}{$\begin{array}{c}\text { Residual } \\
\text { nisin A } \\
\text { (ppm) }\end{array}$} & \multirow{2}{*}{$\begin{array}{l}\mathrm{t}_{\mathrm{lag}} \\
(\mathrm{h})\end{array}$} & \multirow{2}{*}{$\begin{array}{c}\log \\
\mathrm{N}_{0} \\
(\mathrm{Log} \\
\mathrm{cfu} / \mathrm{g}\end{array}$} & \multirow{2}{*}{$\begin{array}{c}\mathrm{Log} \\
N_{\max } \\
(\mathrm{Log} \\
\mathrm{cfu} / \mathrm{g})\end{array}$} & \multirow{2}{*}{$\begin{array}{l}\mu_{\max } \\
\left(\mathrm{h}^{-1}\right)\end{array}$} & \multirow{2}{*}{$\begin{array}{l}\text { Duration } \\
\text { of } \\
\text { experimen } \\
\text { ts (days) }\end{array}$} \\
\hline & & & & & Lactic acid & Acetic acid & Citric acid & & & & & & & \\
\hline 1 & 3 & $10.0 \pm 0$ & $5.9 \pm 0$. & $0.981 \pm 0.00$ & $9,415 \pm 29$ & $2,471 \pm 60$ & $5,030 \pm 26$ & $0.9 \pm \mathrm{N}$ & $0.68 \pm 0.0$ & $63^{1} \pm 16$ & $0.8 \pm 0$ & $4.2 \pm 0.3$ & $0.027 \pm 0.0$ & 21 \\
\hline 2 & 3 & $15.0 \pm 0$ & $6.0 \pm 0$. & $0.983 \pm 0.00$ & $9,132 \pm 14$ & $1,908 \pm 68$ & $3,766 \pm 1,7$ & $0.9 \pm \mathrm{N}$ & $0.68 \pm 0.0$ & ( $7 \pm ? .0$ & $0.9 \pm 0$ & $7.1 \pm 0.1$ & $0.050 \pm 0.0$ & 19 \\
\hline 3 & 3 & $19.5 \pm 0$ & $5.9 \pm 0$. & $0.982 \pm 0.00$ & $9,345 \pm$ & $2,384 \pm 2$ & $4,947 \pm 47$ & $0.9 \pm \mathrm{N}$ & $0.68 \pm 00$ & ก.J \pm 0.0 & $1.0 \pm 0$ & $6.5 \pm 0.1$ & $0.074 \pm 0.0$ & 16 \\
\hline 4 & 3 & $10.0 \pm 0$ & $6.0 \pm 0$. & $0.983 \pm 0.00$ & $9,869 \pm$ & $2,305 \pm 81$ & $5,070 \pm 28$ & $0.8 \pm \mathrm{N}$ & ก 5; +0.6 & $15.2 \pm 22$ & $1.0 \pm 0$. & $4.6 \pm 0.2$ & $0.024 \pm 0.0$ & 21 \\
\hline 5 & 3 & $15.0 \pm 0$ & $6.1 \pm 0$. & $0.981 \pm 0.00$ & $9,364 \pm$ & $2,317 \pm 11$ & $4,710 \pm 11$ & $0.8 \pm \mathrm{N}$ & $0.5 \pm 0.0$ & $0.0 \pm 0.0$ & $1.0 \pm 0$. & $5.4 \pm 0.1$ & $0.045 \pm 0.0$ & 21 \\
\hline 6 & 3 & $19.5 \pm 0$ & $6.1 \pm 0$. & $0.982 \pm 0.00$ & $9,679 \pm 40$ & $2,397 \pm 10$ & $5,234 \pm 44$ & $r .8 \pm V$ & ( $59 \pm 0.0$ & $0.0 \pm 0.0$ & $1.1 \pm 0$. & $5.6 \pm 0.1$ & $0.063 \pm 0.0$ & 16 \\
\hline 7 & 3 & $3.6 \pm 0.3$ & $5.5 \pm 0$ & $0.973 \pm 0.00$ & $1,101 \pm 33$ & $<\mathrm{LOD}$ & $19,39^{5}=x 7$ & $2 . n^{\cdots}$ & $4.21 \pm 0.1$ & $\mathrm{ND}^{\mathrm{f}}$ & $1.9 \pm 0$ & $<1.0 \pm 0.0$ & $0.000 \pm 0.0$ & 33 \\
\hline 8 & 3 & $3.6 \pm 0.3$ & $5.7 \pm 0$ & $0.972 \pm 0.00$ & $1,109 \pm 33$ & $<\mathrm{LOD}$ & $18,19 c^{\prime}+32$ & $2.0 \pm \mathrm{N}$ & $5.28 \pm 0.1$ & ND & $2.0 \pm 0$. & $2.3 \pm 0.2$ & $0.000 \pm 0$ & 35 \\
\hline 9 & 3 & $3.6 \pm 0.3$ & $5.8 \pm 0$. & $0.975 \pm 0.00$ & $1,152 \pm 90$ & $<\mathrm{LOD}$ & 1. $471 \pm د \ni 2$ & $2.0 \pm \mathrm{N}$ & $3.35 \pm 0.1$ & ND & $2.1 \pm 0$. & $<1.0 \pm 0$. & $0.000 \pm 0$ & 33 \\
\hline 10 & 3 & $7.1 \pm 0.3$ & $5.9 \pm 0$. & $0.974 \pm 0.00$ & $1,028 \pm 68$ & $<\mathrm{L} \cap \mathrm{D}$ & $15585 \pm 1,1$ & $2.0 \pm \mathrm{N}$ & $0.88 \pm 0.6$ & $211 \pm 6.3$ & $1.4 \pm 0$. & $10.5 \pm 0$ & $0.023 \pm 0$ & 35 \\
\hline 11 & 3 & $7.1 \pm 0.3$ & $5.4 \pm 0$ & $0.973 \pm 0.00$ & $877 \pm 17$ & $\therefore \mathrm{OD}$ & $20,864 \pm 438$ & $2.0 \pm \mathrm{N}$ & $3.56 \pm 0.1$ & ND & $1.2 \pm 0$ & $<1.0 \pm 0$ & $0.000 \pm 0$ & 32 \\
\hline 12 & 3 & $7.1 \pm 0.3$ & $5.7 \pm 0$ & $0.976 \pm 0.00$ & $958+9$ & LOD & $17,172 \pm 699$ & $2.0 \pm \mathrm{N}$ & $4.38 \pm 0.2$ & ND & $1.6 \pm 0$. & $<1.0 \pm 0$. & $0.000 \pm 0$ & 35 \\
\hline 13 & 3 & $11.3 \pm 0$ & $5.8 \pm 0$ & $0.970 \pm 0.00$ & $100, \pm 2$ & $<$ LOD & $17,721 \pm 235$ & $2.0 \pm \mathrm{N}$ & $0.98 \pm 0.0$ & $31.6 \pm 4$ & $1.7 \pm 0$ & $8.7 \pm 0.1$ & $0.058 \pm 0$ & 18 \\
\hline 14 & 3 & $11.3 \pm 0$ & $5.6 \pm 0$. & $0.971 \pm 0.00$ & $1,\left\llcorner^{51} \_47\right.$ & $<\mathrm{LOD}$ & $18,660 \pm 442$ & $2.0 \pm \mathrm{N}$ & $1.07 \pm 0.1$ & $27.1 \pm 11$ & $1.2 \pm 0$ & $8.5 \pm 0.1$ & $0.046 \pm 0$ & 21 \\
\hline 15 & 3 & $11.3 \pm 0$ & $5.6 \pm 0$. & $0.970 \pm 0.00$ & $869 \pm 23$ & $<$ LOD & $18,340 \pm 710$ & $2.0 \pm \mathrm{N}$ & $0.56 \pm 0.0$ & $0.0 \pm 0.0$ & $0.8 \pm 0$. & $8.2 \pm 0.1$ & $0.040 \pm 0$ & 21 \\
\hline
\end{tabular}

${ }^{\mathrm{a}}$ Avg: average; SD: standard deviation.

${ }^{\mathrm{b}}$ Challenge test. Challenge tests 1-6 performed using processed cheese (PC) and 7-15 with spreadable processed cheese (SPC).

${ }^{\mathrm{c}}$ Number of growth curves per experiment.

${ }^{\mathrm{d}} \mathrm{P} 1$ : orthophosphate salt.

${ }^{\mathrm{e}} \mathrm{NA}$, not available. Information not provided by Eurofins.

${ }^{\mathrm{f}} \mathrm{ND}$ : not determine. 


\section{Journal Pre-proof}

Table 5. Comparison of observed and predicted growth and no-growth responses of L. monocytogenes in processed cheese containing nisin ${ }^{\mathrm{a}}$.

Predicted responses by three available models including the effect of nisin A

\begin{tabular}{|c|c|c|c|c|c|c|}
\hline Models and responses ${ }^{\mathrm{a}}$ & $\begin{array}{r}\text { Parent } \\
\text { Probability }\end{array}$ & $\begin{array}{l}\text { (1998); } \\
\text { vival in } 1 \mathrm{ml}\end{array}$ & $\begin{array}{c}\text { Bouttefroy } \\
\text { Viable populat }\end{array}$ & $\begin{array}{l}\text { l. }(2000) \\
\log _{10} \mathrm{cfu} / \mathrm{ml}\end{array}$ & $\begin{array}{r}\text { Boziaris and } \\
\text { Probabil }\end{array}$ & $\begin{array}{l}\text { chas (2006); } \\
\text { f growth }\end{array}$ \\
\hline \multirow[t]{2}{*}{ Factors included in model } & \multicolumn{2}{|c|}{$\mathrm{pH}, \mathrm{NaCl}, \mathrm{EDTA}$, nisin } & \multicolumn{2}{|c|}{$\mathrm{pH}, \mathrm{NaCl}$, nisin } & \multicolumn{2}{|c|}{$\mathrm{T}, \mathrm{a}_{\mathrm{w}}, \mathrm{pH}$, nisin } \\
\hline & $\begin{array}{c}\text { Added nisin } \\
\mathrm{A}^{\mathrm{b}}\end{array}$ & $\underset{\mathrm{A}^{\mathrm{c}}}{\text { Residual nisin }}$ & $\begin{array}{c}\text { Added nisin } \\
\mathrm{A}^{\mathrm{b}}\end{array}$ & $\begin{array}{c}\text { Residual nisin } \\
A^{c}\end{array}$ & $\begin{array}{c}\text { Added nisin } \\
\mathrm{A}^{\mathrm{b}}\end{array}$ & $\underset{\mathrm{A}^{\mathrm{c}}}{\text { Residual nisin }}$ \\
\hline Correct $(\%)$ & 14 & 3 & 86 & 86 & 14 & 100 \\
\hline Fail-safe $(\%)$ & 0 & 11 & 0 & & 0 & 0 \\
\hline Fail-dangerous (\%) & 86 & 86 & 14 & 0 & 86 & 0 \\
\hline
\end{tabular}

a Observed responses included 45 kinetics of which 30 showed growth and 15 showed no-growth

${ }^{\mathrm{b}}$ Added nisin A: 11.2-12.0 ppm.

${ }^{\mathrm{c}}$ Nisin A measured by LC-MS/MS: 0.59-5.28 ppm. 


\section{Journal Pre-proof}

Table 6. Growth kinetic parameters of L. monocytogenes in processed cheese containing nisin A and goodness of fit indices for the two-steps (eq. (S3); eq, (4)) and the global (one-step, eq. (5)) regression approaches.

\begin{tabular}{|c|c|c|c|c|c|c|}
\hline \multirow{2}{*}{ Modelling approaches } & \multirow{2}{*}{$\begin{array}{c}\text { Growth and growth } \\
\text { boundary model }\end{array}$} & \multicolumn{2}{|c|}{$\mathrm{RLT}^{\mathrm{a}}$ secondary model } & \multirow[t]{2}{*}{$\begin{array}{c}\log \left(N_{\max },\right. \\
\mathrm{cfu} / \mathrm{g})\end{array}$} & \multicolumn{2}{|c|}{ Goodness of fit } \\
\hline & & $k 1$ & $k 2$ & & $\mathrm{RSS}^{\mathrm{b}}$ & $\operatorname{RMSE}^{\mathrm{c}}$ \\
\hline Classical two-step approach & 0.510 & 0.0 & 1957 & 6.60 & 465 & 1.21 \\
\hline Global (one-step) regression & 0.629 & 0.0 & 2087 & 6.60 & 393 & 0.97 \\
\hline
\end{tabular}

${ }^{a}$ RLT: relative lag time

${ }^{\mathrm{b}} \mathrm{RSS}$ : residual sum of squares

${ }^{c}$ RMSE: root mean square error 


\section{Journal Pre-proof}

Table 7. Observed and predicted growth and no-growth responses for L. monocytogenes.

\begin{tabular}{|c|c|c|c|c|c|}
\hline \multicolumn{3}{|c|}{ Observed } & \multicolumn{3}{|c|}{ Predicted } \\
\hline $\mathrm{n}^{\mathrm{a}}$ & Growth & $\begin{array}{c}\text { No } \\
\text { growth }\end{array}$ & $\begin{array}{l}\text { Assuming no } \\
\text { added } \\
\text { Nisin A }\end{array}$ & $\begin{array}{l}\text { Residual nisin } \\
\text { A }\end{array}$ & $\begin{array}{l}\text { Nisin A } \\
\text { added to } \\
\text { formulation }\end{array}$ \\
\hline \multirow[t]{4}{*}{45} & 30 & 15 & $0 \mathrm{ppm}$ & $0.59-5.28 \mathrm{ppm}$ & $11.2-12 \mathrm{ppm}$ \\
\hline & \multicolumn{2}{|c|}{ Correct (\%) } & 86 & 100 & 14 \\
\hline & \multicolumn{2}{|c|}{ Fail-safe $(\%)$} & 14 & 0 & 0 \\
\hline & \multicolumn{2}{|c|}{ Fail-dangerous (\%) } & 0 & 0 & 86 \\
\hline
\end{tabular}

${ }^{a}$ Number of growth curves: a total of 15 challenge tests with triplicate measurements. 


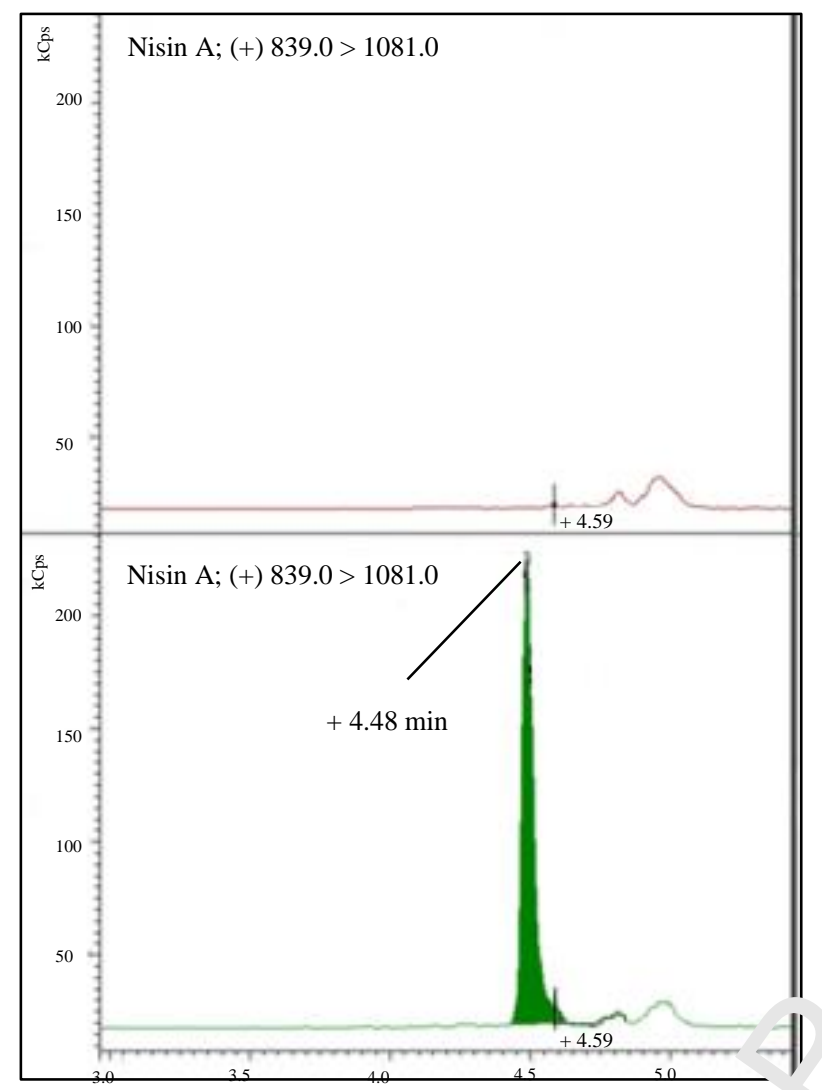

Figure 1. Chromatogram obtained after LC-MS/ ${ }^{\circ} \mathrm{S}$ analysis of cheese with non-spiked (top) and spiked (bottom) with nisin $\mathrm{A}(0.5 \mathrm{mg} / \mathrm{kg})$. 

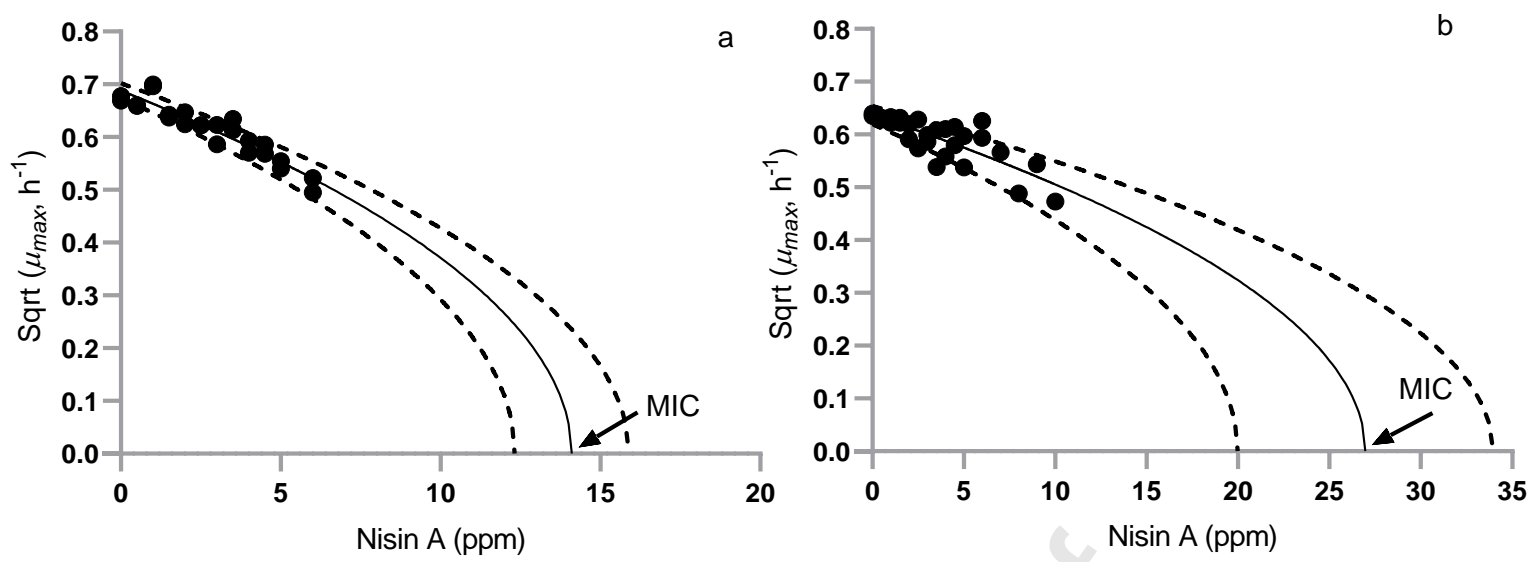

Figure 2. Effect of nisin A on maximum specific growth rates $\left(\mu_{\max }, \mathrm{h}^{-1}\right)$ if $L$. nonocytogenes LM13 (a) and LM4R (b)

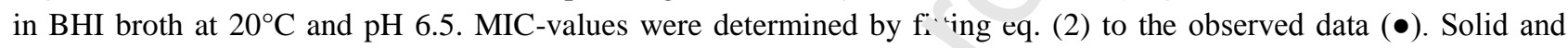
dashed lines represent the fitted values and confidence intervals $\left(95^{\circ} \%\right.$, espectively. 


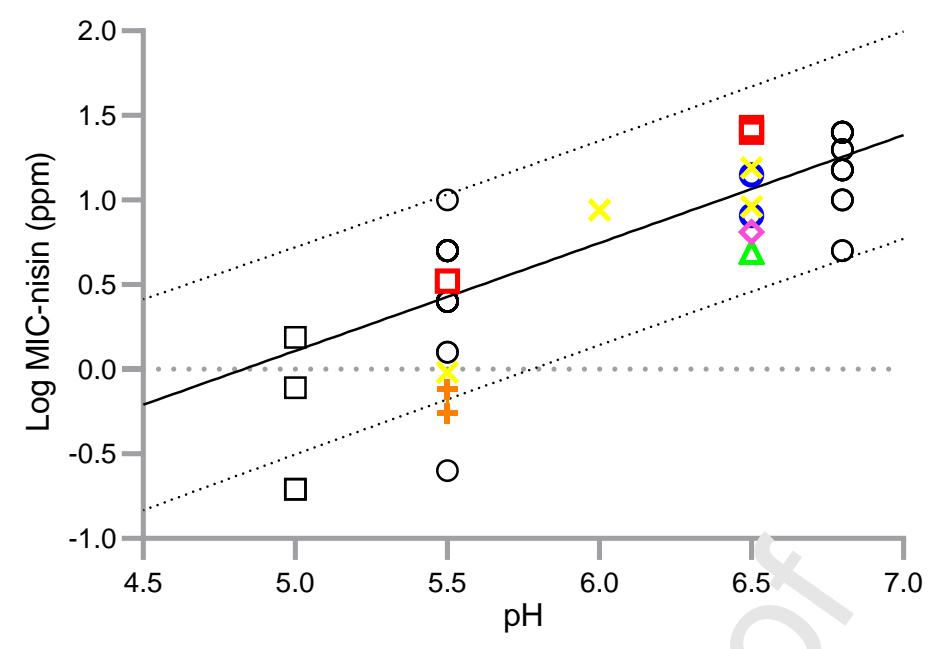

Figure 3. Effect of $\mathrm{pH}$ on nisin A MIC-values for L. monocytogene; i dr cermined in the present study and from literature. Data for a cocktail of L. monocytogenes strains [Lm-mix: CI U ?, 612, LM19, 6 (X)], individual strains [LM

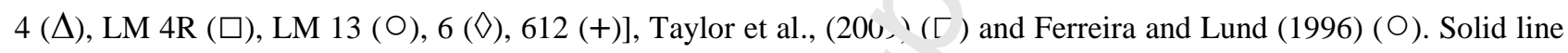
(-) and dashed line (- - - ) represent, respectively, the fitted mode. (eq. (j)) and confidence interval (95\%) 


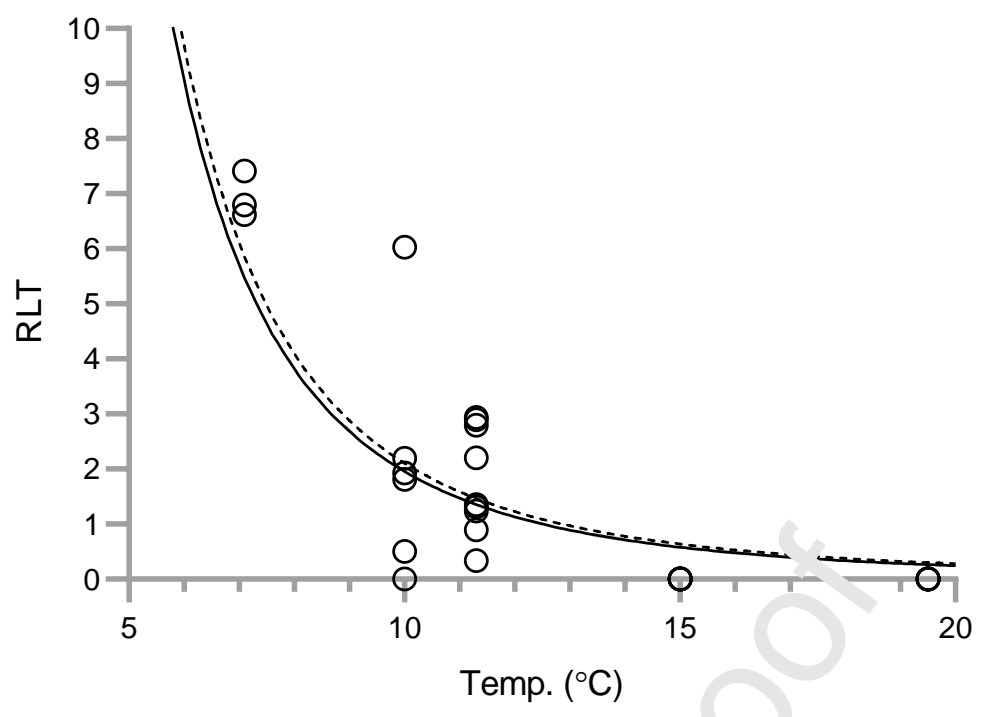

Figure 4. Effect of storage temperature on observed and fitted $\mathrm{re}^{1} \mu$ a $ı \mathrm{~g}$ time (RLT) values for L. monocytognees growing in processed cheese containing nisin A. The two-step ap. acl (solid line) and the global regression (dashed line) were used to fit RLT-values (Table 6). 

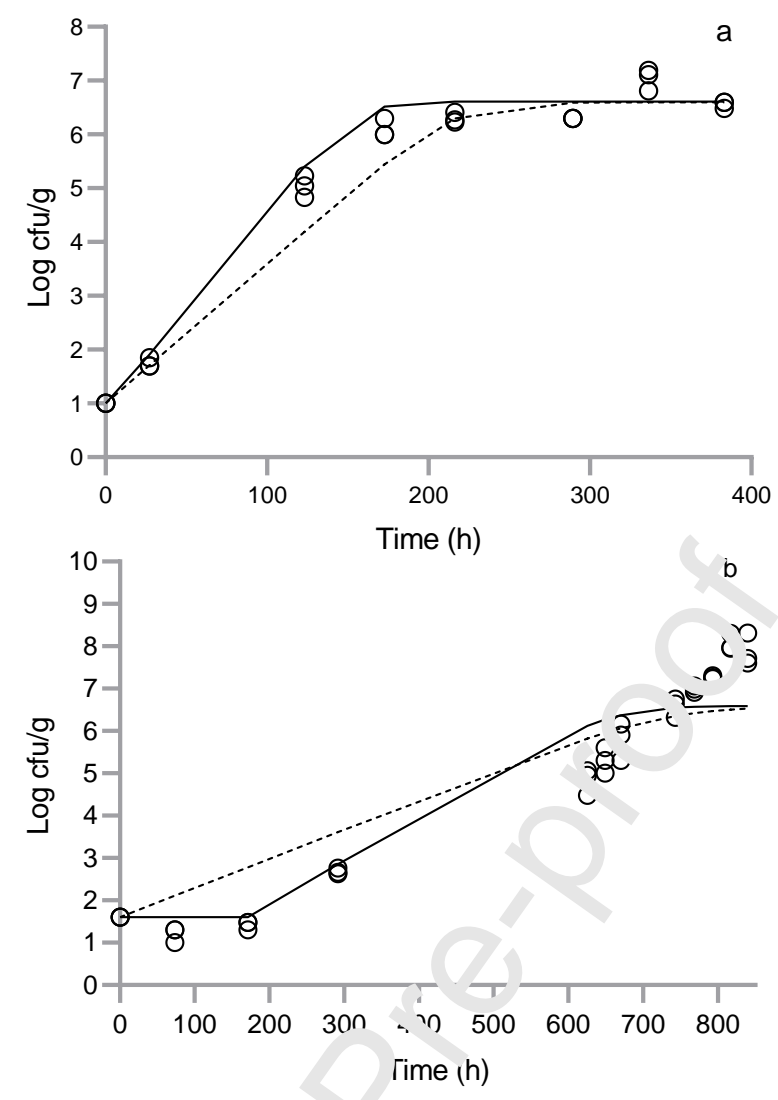

Figure 5. Growth of L. monocytogenes $(\mathrm{O})$ in ${ }^{\circ} \mathrm{n}_{\mathrm{L}}$. nercial (a) and laboratory made (b) processed cheese containing nisin and stored at $19.5^{\circ} \mathrm{C}$ or $7.3^{\circ} \mathrm{C}$, respective y, C 3 , CT 10; Table 4). Solid lines indicate predictions obtained with the model developed in the present study ( 4 . '5) and Table 6) and dashed lines indicate predictions obtained with the model of Martinez-Rios et al. (2019a) inc'uc 'ng (eq. (S1)). 


\section{Highlights}

- New model to predict growth of Listeria monocytogenes in processed cheese containing nisin

- Model including the effect of temperature, $\mathrm{pH}, \mathrm{a}_{\mathrm{w}}$, lactic acid, acetic acid, citric acid, orthophosphate and nisin

- LC-MS/MS method was developed and validated to quantify nisin A present in cheese 